University of Nebraska - Lincoln

DigitalCommons@University of Nebraska - Lincoln

Papers in Ornithology

Papers in the Biological Sciences

1961

Evolutionary Relationships among the North American Mallards

Paul A. Johnsgard

University of Nebraska-Lincoln, pajohnsgard@gmail.com

Follow this and additional works at: https://digitalcommons.unl.edu/biosciornithology

Part of the Ornithology Commons

Johnsgard, Paul A., "Evolutionary Relationships among the North American Mallards" (1961). Papers in Ornithology. 62.

https://digitalcommons.unl.edu/biosciornithology/62

This Article is brought to you for free and open access by the Papers in the Biological Sciences at DigitalCommons@University of Nebraska - Lincoln. It has been accepted for inclusion in Papers in Ornithology by an authorized administrator of DigitalCommons@University of Nebraska - Lincoln. 


\title{
EVOLUTIONARY RELATIONSHIPS AMONG THE NORTH AMERICAN MALLARDS
}

\author{
Paul A. Johnsgard
}

This study is the report of an attempt to understand the evolutionary relationships existing within a group of mallardlike ducks native to North America. The group includes the Common Mallard, Anas platyrhynchos platyrhynchos L.; the Black Duck, Anas rubripes Brewster; the Florida Duck, Anas fulvigula fulvigula Ridgway; the Mottled Duck, Anas fulvigula maculosa Sennett; the Mexican Duck, Anas diazi diazi Ridgway; and the New Mexican duck, Anas diazi novimexicana Huber. All but one of these (the Common Mallard) are restricted to North America, and all these American forms possess a sexually nondimorphic plumage. In all other respects they are extremely similar to the Common Mallard, and a study of their relationships to this form was believed possibly to provide an instructive example of speciation.

\section{Review of Ranges, Populations, and Nomenclature}

The Mexican and New Mexican Ducks

In 1886 Ridgway described a new species of mallard (Anas diazi) from Puebla, Mexico, which, similar to the then recently (1874) described Florida Duck, differed from the Common Mallard (Anas platyrhynchos) in its lack of sexual dimorphism. According to Ridgway, the new species differed from the Florida Duck in its more Mallardlike characteristics, namely the distinct band of white on the secondary wing coverts and its less-fulvous over-all coloration. Thirty-six years later, Huber (1920) described another species of mallard from New Mexico, which he named Anas novimexicana. Huber was seemingly unaware of the similarities shown by the New Mexican Duck to the Mexican Duck, but in 1922 Conover referred to an extralimital Nebraskan specimen as Anas diasi novimexicana, and Phillips (1924) treated the New Mexican Duck in the same manner in his monograph. Although the close relationship between the New Mexican and the Mexican ducks was therefore realized relatively early, the paucity of specimens and field observations made the exact geographic relationship between the two forms uncertain. In 1946 Lindsey summarized the situation as follows: "The known nesting range of the New Mexican Duck is confined to a small area of the south-western United States, but the presumptive range extends southwards into Chihuahua, Mexico, where its relation to the northern breeding limits of the Mexican Duck (A. diazi diazi) is undetermined." 


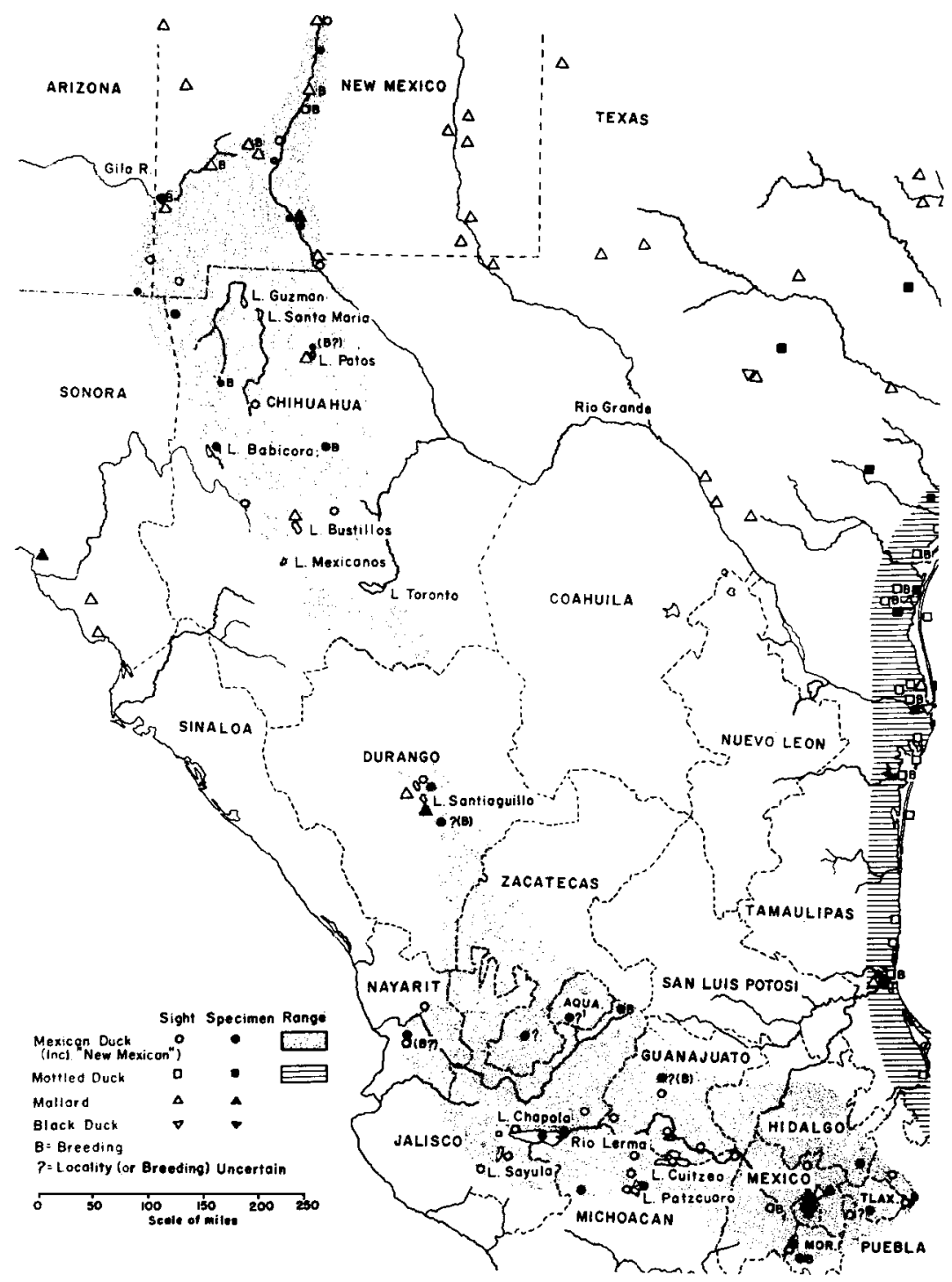

Figure 1. Geographic range of Mexican (including "New Mexican") Duck.

An attempt has been made to map the geographic ranges of the Mexican and New Mexican ducks, and thus to help visualize their geographic relationships. This was done by plotting all available specimen records and such sight records as appeared justified from the literature, personal communications, and the major United States collections. The 
resulting map (Figure 1) shows fairly close agreement with the comparable maps of Delacour (1956), Arellano and Rojas (1956), and Leopold (1959). It follows the map of Leopold in indicating an unbroken range between the New Mexican and Mexican populations, although records are spotty for the area in question. If birds at the northern parts of the range are migratory, for which there is some evidence, it is probable that they winter in the heart of the range of diazi; habitat conditions are very poor on the Chihuahua lakes, and they are unattractive to waterfowl (Saunders and Saunders, 1949).

Of all the races of North American mallards, perhaps least is known about the Mexican Duck, and this is certainly the case regarding the total population size. Since 1947 the U.S. Fish and Wildlife Service has surveyed the lakes of interior Mexico during its annual January waterfowl inventories. Mr. R. H. Smith, who has flown this route each year since 1951, has provided (in litt.) the data obtained for the Mexican Duck during these years. The smallest total number of Mexican Ducks recorded was 780 in 1951, and the largest total was 10,322 in 1958 . Although the northern Chihuahuan lakes-Toronto, Bustillos, and Mexicanos-were surveyed, it is of interest that no Mexican Ducks have been recorded there; Lago Santiaguillo, Durango, is apparently the northern wintering limit of the Mexican Duck in Mexico. Its western limit would appear to be Lago Sayula, Jalisco, and the eastern limit in the marshy region near Oriental, Puebla. These data would indicate that the size of the adult Mexican Duck population is probably less than 20,000 birds. New Mexican game biologists have estimated that the population in their state is extremely small, possibly not over 100 adult birds.

\section{The Florida and Mottled Ducks}

In 1874 Ridgway described a new form of mallard from St. Johns, Florida, which he considered to be a subspecies of the Black Duck. As the Black Duck was at that time called Anas obscura, the new bird was named Anas obscura var. fulvigula. It differed mainly from the Black Duck in that the malar region, chin, and throat were immaculate buff rather than streaked with dusky, and the plumage had a general ochraceous, rather than dusky, tone. At the time it was known only from Florida. Later (1878) Ridgway relegated it to the rank of a full species, Anas fulvigula. Eleven years later, Sennett (1889) described from Texas yet another species of mallard, which he called Anas maculosa. Sennett stated that the most marked differences between A. fulvigula and $A$. maculosa were the latter's streaked, rather than plain buff, cheeks and a green, rather than purple, speculum in addition to a mottled, rather than streaked, general coloration. The Mottled Duck 
was added to the A.O.U. Check-list in 1890 as Anas fulvigula maculosa, and no later arguments for retaining the specific status of maculosa have been presented.

Although Phillips had vacillated earlier between accepting and rejecting the Mottled Duck and Florida Duck as distinct races, in 1924 he synonymized the two forms. Later, Peters (1931) accepted maculosa as being distinct from fulvigula, although Delacour and Mayr (1945) as well as Hellmayr and Conover (1948) synonymized them. The form maculosa is still accepted by the A.O.U. Check-list.

Regardless of the question of the validity of the described plumage differences, which will be discussed later, a definite hiatus in the ranges of the populations seems to exist. The range of the Florida Duck (see Figure 2, which is modified from Howell, 1932, and Sprunt, 1954) is largely confined to the southern half of peninsular Florida, with its northern limits being in the vicinity of Gainesville. There are apparently no specimens of fulvigula or maculosa that have been taken in Mississippi. A single specimen has been taken in Alabama (Imhof, 1958) and may represent either fulvigula or maculosa. In addition, several sight records along the coast of Alabama have been obtained for Florida or Mottled ducks. Mottled Ducks occur commonly almost to the eastern border of Louisiana (Oberholser, 1938). They are found mainly in the coastal tier of parishes of Louisiana (Lowery, 1955) west to the Texas border, and in Texas likewise follow the coastal counties for the entire length of the state (Singleton, 1953). The range of the Mottled Duck also extends a long distance into Mexico (Saunders, 1952, 1953 ) in the states of Tamaulipas and Veracruz. The range map presented in Figure 2 is a composite of information from the sources cited above, and from additional sight and specimen records available to me.

The Florida Game and Fresh Water Fish Commission has taken a census of the Florida Duck population annually since 1948 by the aerial transect method. During the years 1948 to 1955, the estimated total adult population varied from 17,000 to 30,000 (Sincock, 1957). The 1956 and 1957 inventory estimates for the entire state were 9,000-16,000 and 7,000-10,000 birds, respectively, indicating, according to Sincock, a sharp drop in Florida Duck numbers in recent years. A reasonable estimate of the present total adult Florida Duck population would appear to be 10,000 .

In Louisiana, inventories of the Mottled Duck population have been made yearly since 1952. Estimates in recent years have averaged about 10,000 birds (M. M. Smith, in litt.), which are spread out fairly evenly over the marshes of southeast and southwest Louisiana, being especially 


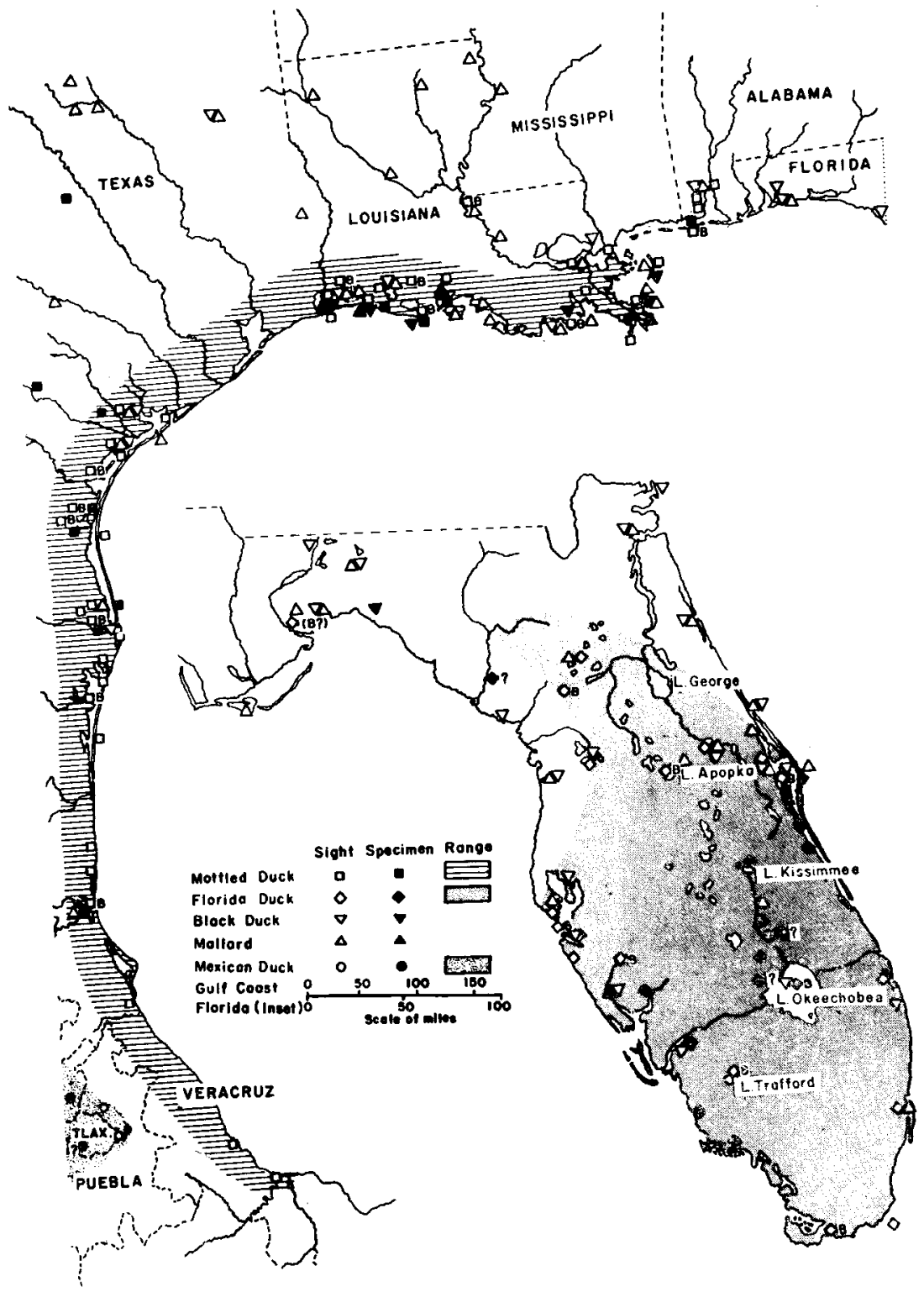

Figure 2. Geographic ranges of Mottled and Florida ducks. 
frequent in the salt and brackish marshes of the coast. In Texas the coastal waterfowl surveys for the years 1947 to 1952 provide an estimate of winter Mottled Duck populations in that state (Singleton, 1953). Mottled Ducks during these five years averaged over 7,000 birds in October (maximum of 23,000 in 1947), decreasing monthly to an average minimum of from 1,000 to 2,000 birds from November through February. Estimated summer Mottled Duck populations over a 26,000-square-mile area were 18,500 in March and 21,000 in August 1952. These birds are distributed over the entire coastal prairie region, extending inland from 50 to 70 , or possibly 100 , miles (Singleton, 1953).

Little can be said regarding the size of the Mexican population of Mottled Ducks. Saunders (1953) reports that "several hundred" have been seen during the January inventories along the Mexican coast, and Saunders and Saunders (1949) state that ground studies in Tamaulipas and Veracruz indicated that several thousand birds are present. In summary, the total Mottled Duck population might be estimated at 30,000 adult birds in the United States plus an additional number, possibly not over 5,000, in Mexico.

\section{The Black Duck}

Gmelin described the American Black Duck in 1788 as Anas obscura, based on Pennant's "Dusky Duck" from New York. This name was used until 1908, when Anas obscura was found to be preoccupied (Allen, et al., 1908). In 1902, however, Brewster had described a subspecies of the Black Duck, which he called rubripes, and thus this name was taken for the specific epithet to replace obscura. This left Brewster without a name for his newly described form, a condition he rectified in 1909 by proposing tristis. The ensuing arguments for (Brewster, 1910; Phillips, 1920; Townsend, 1912) and against (Dwight, 1919; Pirnie, 1928; Shortt, 1943) the admission of tristis have filled many pages, and the long-delayed acceptance (1931) of this form by the A.O.U. Check-list committee was withdrawn in 1945 following Shortt's (1943) careful analysis of seasonal variations in soft-part coloration. The present consensus that tristis is not an admissible form is followed here.

In 1945 Delacour and Mayr stated that "it seems obvious that the Mexican and Black Ducks are only sub-specifically distinct from the Dusky Duck" (fulvigula), and consequently the Black Duck was treated in their revision as Anas fulvigula rubripes. However, in 1956 Delacour modified his opinion regarding the Mexican and Florida ("Dusky") ducks' affinities, stating that the latter will mate preferentially with the Common Mallard rather than the Black Duck, and so restored the name Anas rubripes to the Black Duck. 
The recent treatise by Stewart (1958) on the distribution of the Black Duck is a thorough and detailed account that can scarcely be improved. His maps of the wintering and breeding ranges of the Black Duck agree well with the data collected during the present study, and are adopted in simplified form (Figure 3) here. Stewart divided the eastern United States into six regions of approximately equal size (indicated in Figure 5 ), and determined the average wintering Black Duck populations for each region, based on the annual January U.S. Fish and Wildlife Service inventories for the five years 1952-1956. These data, rounded to the nearest 1,000 , appear in Table 1 , together with the average percentage

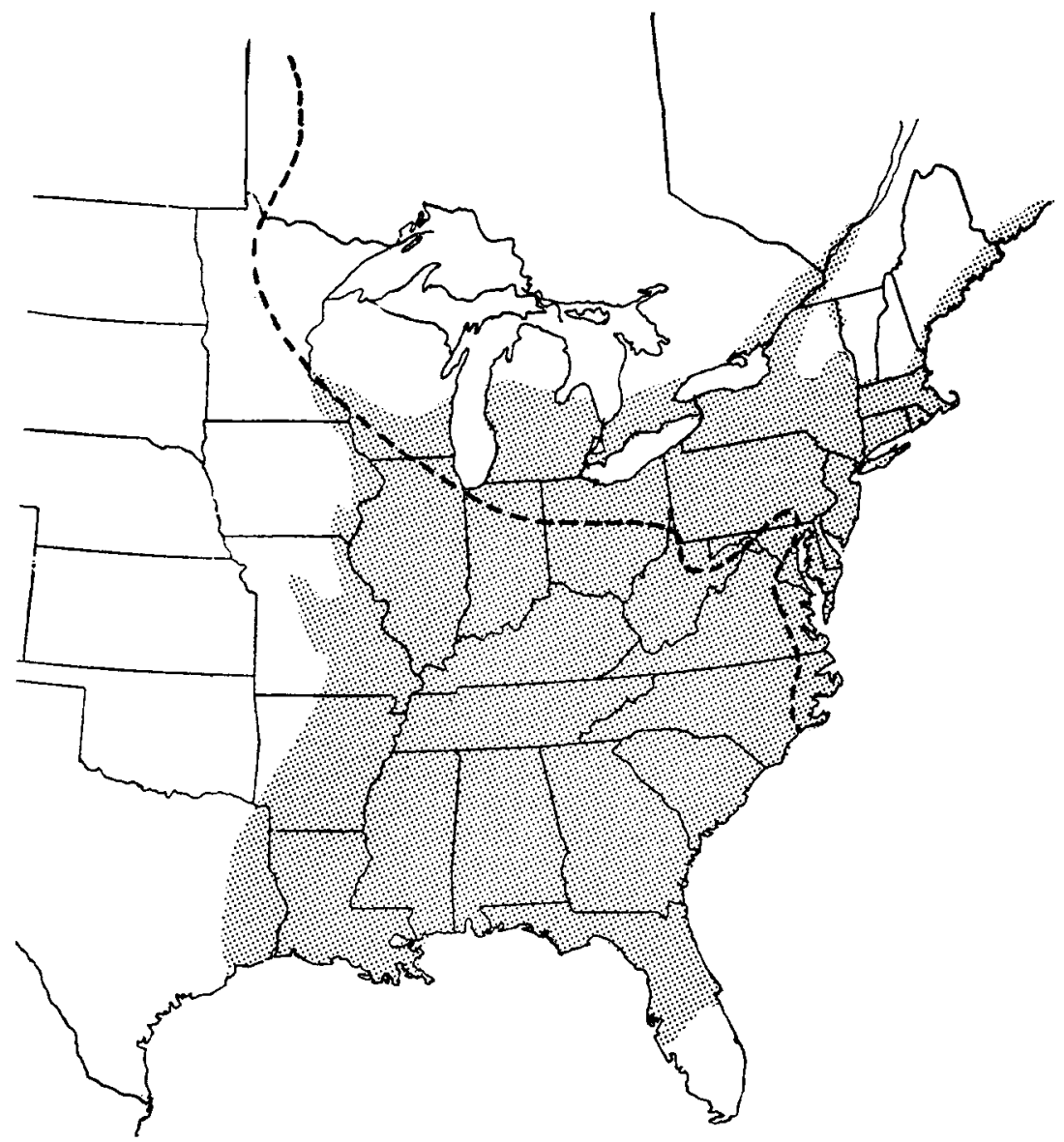

Figure 3. Southern limit of breeding (broken line) and wintering (shaded) ranges of Black Duck. 
TABLE 1

Regional Distribution of Wintering Black Ducks

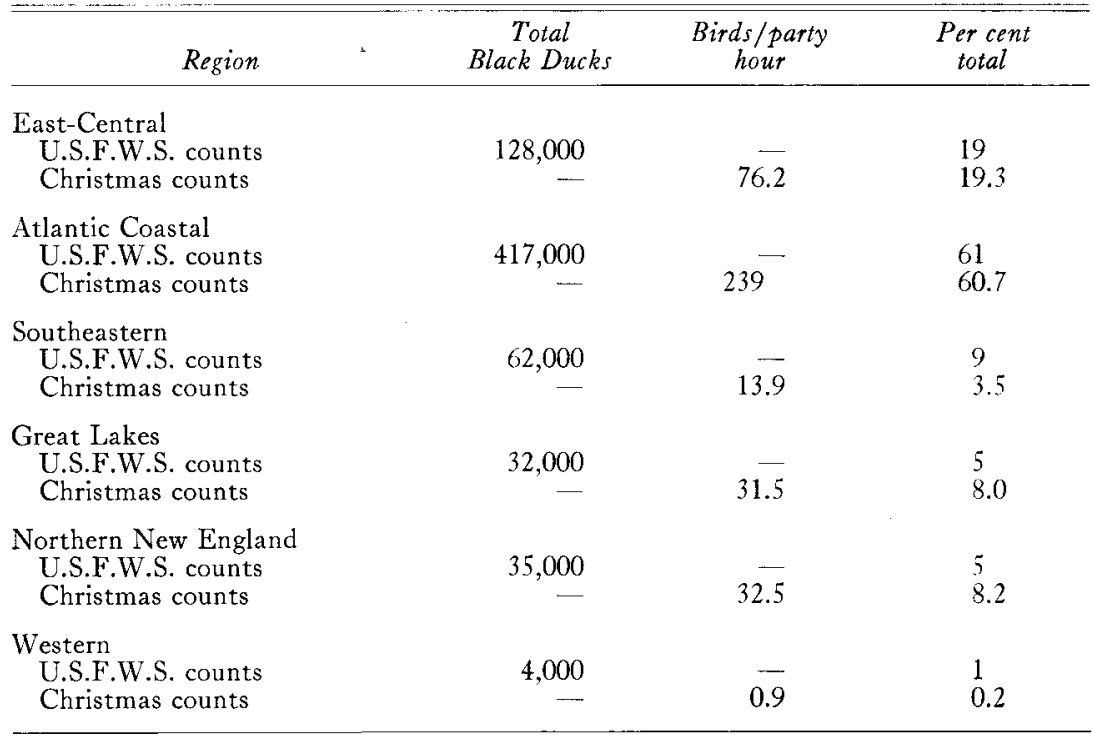

of the total U.S. population observed in each region. In addition are included comparable data compiled from the annual Audubon Christmas counts for the years 1950-1957. Because the numbers of observers vary greatly in different areas, average total Black Ducks recorded per party hour (for all counts on which Black Ducks were observed) are listed, rather than average total numbers of Black Ducks seen. A breakdown of these data by states is also presented in Figure 4, providing a more detailed comparison of Black Duck wintering densities throughout the eastern states. These two sets of data, obtained by widely differing means, agree remarkably well in regard to the relative distribution of the total wintering population. The only area of poor agreement is in the southeastern states, where a difference of 5.5 per cent occurs. This difference is at least partly explained by the fact that in Florida and Louisiana the Fish and Wildlife inventories include Florida and Mottled ducks with Black Ducks, since they cannot be distinguished during aerial counts. This factor tends to exaggerate estimated Black Duck populations in these states.

Total numbers of Black Ducks estimated on these annual January inventories provide the best available indication of population size, although these survey data cannot be considered to be completely accurate estimates of actual numbers of wintering Black Ducks (Stewart, 


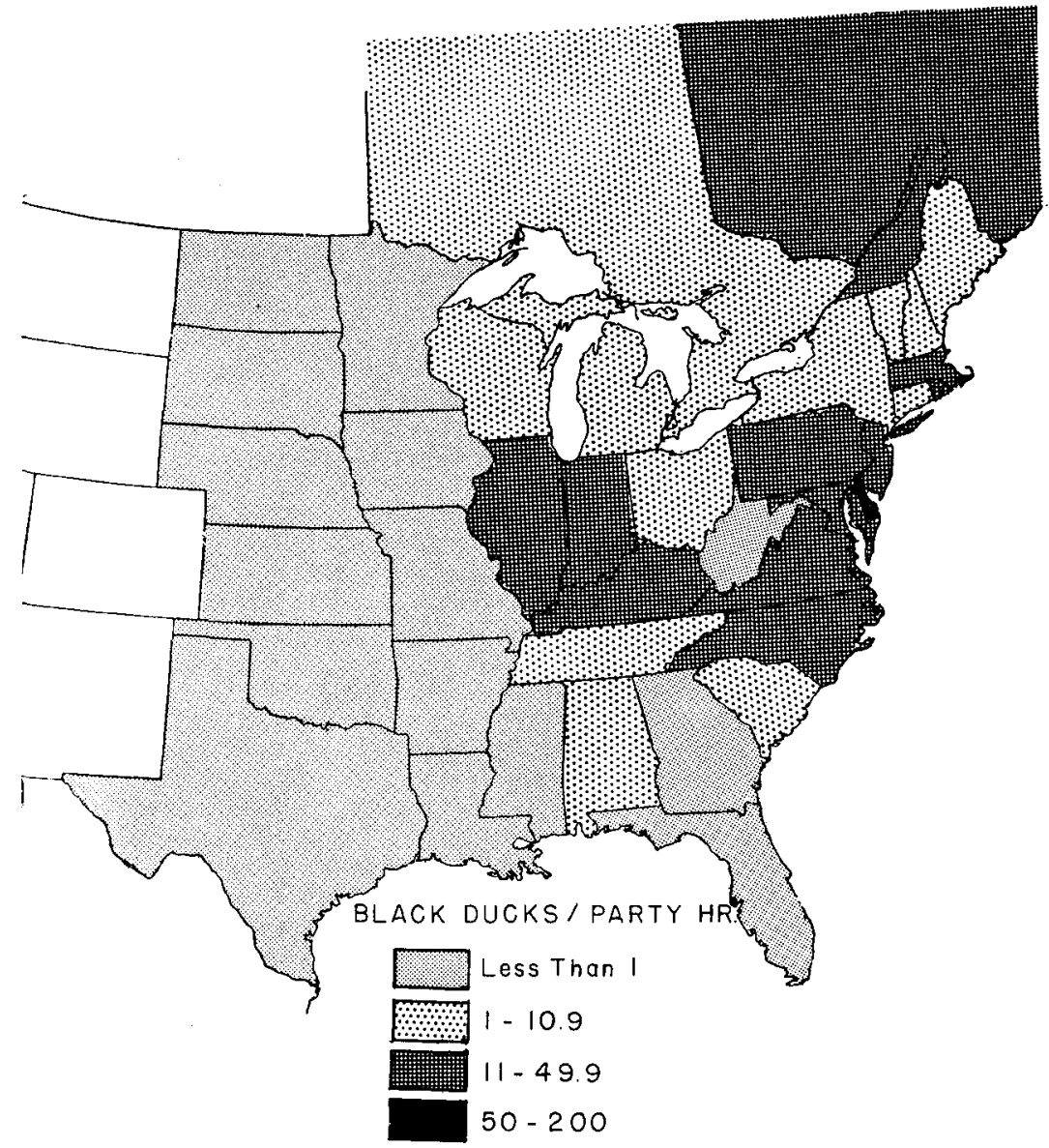

Figure 4. Relative densities of wintering Black Ducks, eastern states.

1958). During the five years included in Stewart's study, this average total population figure was approximately 678,000. If the 1957 and 1958 inventories are included, the seven-year average is 647,000 birds, which will be used here as an estimate of the total Black Duck population.

\section{The Common Mallard}

The Common, or Green-headed, Mallard was described by Linneaus in 1758 as Anas platyrhynchos in the 10th edition (p. 125) of his Systema Naturae. Previous to 1906, it was generally referred to as Anas boschas, before the page priority of platyrhynchos was established (Lönnberg, 1906). The species occurs throughout the northern hemisphere, and has 
one of the widest breeding distributions of any species of waterfowl in the world.

Because of the rarity of this species in the eastern states during the colonial period, the Mallard (unless uncapitalized, the common name Mallard is used here to mean $A$. p. platyrhynchos) was not recognized as a common species in the United States, since it was replaced in the East by the Black Duck. Evidently it was not before the late 1800's that the Mallard began to move noticeably eastward, as indicated by the scarcity of references to it before 1900. Brewster (1906), referring to the Cambridge region, states: "During the earlier years of my shooting experience the Mallard was unknown to our local gunners, and everywhere throughout New England was considered a rare bird. Within the past decade, however, it has become a regular and not uncommon visitor in autumn to several localities in eastern Massachusetts. . . " Townsend (1905) indicates a similar situation in the same region.

At present the Mallard must be considered a fairly numerous nesting species throughout the East, at least as far east as central New York. Although Maine probably may not yet be considered as within the nesting range of the Mallard, this species has been observed there with increasing frequency, and recently (1953) Coulter provided the first two definite nesting records for that state. At present Mallards and Mallard $\mathrm{x}$ Black Duck hybrids comprise approximately 1 per cent of the fall hunter kill in Maine (Coulter, 1954). In Ontario Mallards have increased greatly around the Toronto area (Goodwin, 1956), and to the north nest as far east as the James Bay region (Manning, 1952).

For the purposes of comparison with the Black Duck, a map showing the breeding and wintering distribution of the Mallard in the eastern states has been prepared (Figure 5). The breeding range has been modified from previous range maps (Kortright, 1942; Phillips, 1924) to show the eastern extension of the breeding range, and the winter distribution is based mainly on an analysis of the Audubon Christmas count data. Local areas of winter concentration are indicated. To provide an additional comparison with the Black Duck (Figure 4), the average total Mallards recorded per party hour (for all counts where Mallards were seen) have been calculated for each state for the period 1950-1957, and these data are presented in Figure 6.

Because only that portion of the Mallard population that is sympatric with the Black Duck is of biological importance from the practical standpoint of actual interaction between the two gene pools, only an estimate of the Mallard populations of the eastern states (Mississippi and Atlantic 
flyways) will be attempted. It should be remembered, however, that the potential gene pool of the Mallard, if the Central and Pacific flyway (plus European and Asian) populations are considered, is actually immensely greater.

Again, the most satisfactory source of quantitative information on the size of Mallard populations is the Fish and Wildlife Service January inventories. For the Atlantic flyway, data from these counts are shown below for the 10-year-period 1949-1958, whereas for the Mississippi flyway they are available for the nine-year-period 1950-1958.

\begin{tabular}{lccc}
\hline & $\begin{array}{c}\text { Average total } \\
\text { Mallards }\end{array}$ & $\begin{array}{c}\text { Average total } \\
\text { Black Ducks }\end{array}$ & $\begin{array}{c}\text { Ratio } \\
\text { Mallard: Black }\end{array}$ \\
\hline Atlantic flyway & 218,000 & 457,000 & $32.2: 67.8$ \\
Mississippi flyway & $3,566,000$ & 190,000 & $97.5: 2.5$ \\
Total eastern U.S. & $3,784,000$ & 647,000 & $85.4: 14.6$ \\
\hline
\end{tabular}

A check on the accuracy of these data is provided by a similar calculation of Mallards and Black Ducks observed per party hour during the Audubon Christmas counts over essentially the same period of years (1950-1957). Although actual numerical comparisons cannot be made, it is possible to obtain an index to relative densities of Mallards and Black Ducks by summing the average numbers of both forms recorded per party hour for all states within each flyway and obtaining ratios on the relative abundance of the two forms:

\begin{tabular}{lccc}
\hline \hline & $\begin{array}{c}\text { Cumulative } \\
\text { Mallards } \\
\text { per party hour }\end{array}$ & $\begin{array}{c}\text { Cumulative } \\
\text { Black Ducks } \\
\text { per party hour }\end{array}$ & $\begin{array}{c}\text { Ratio } \\
\text { Mallard: Black }\end{array}$ \\
\hline Atlantic flyway & 113.27 & 297.09 & $27.6: 72.4$ \\
Mississippi flyway & $2,259.06$ & 97.14 & $95.9: 4.1$ \\
Total eastern U.S. & $2,327.33$ & 394.23 & $85.5: 14.5$ \\
\hline
\end{tabular}

These two sets of data show extremely close agreement with one another, particularly in regard to the estimated ratio of Mallards to Black Ducks for the two flyways combined, where a disagreement of less than 1 per cent is found. It seems safe, therefore, to state that in the eastern United States the Mallard population outnumbers the Black Duck at the present time by approximately six to one. 


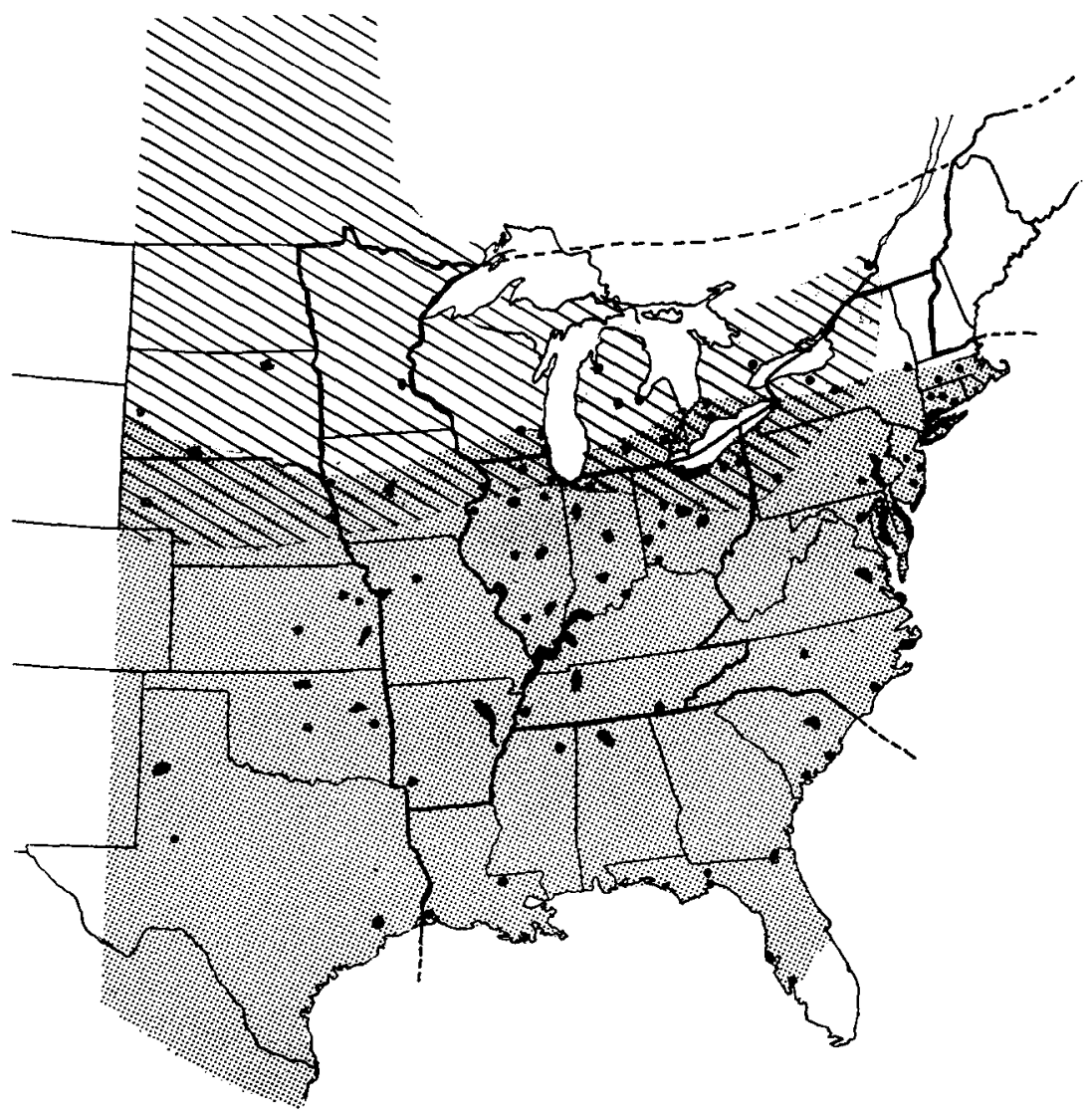

Figure 5. Breeding (ruled lines) and wintering (shaded) ranges of Common Mallard in eastern states. Blacked-in areas indicate major wintering concentrations.

\section{Morphological Charicteristics}

The various plumage and soft-part differences attributed to each of the sexually nondimorphic forms can be summarized as follows:

The Mexican and New Mexican ducks. According to Ridgway (1886). the Mexican Duck is most like the Florida Duck, differing in its double band of white on the wings, its less-fulvots coloration, its streaked cheeks, and in its lack of a black spot on the base of the maxilla. From the Mallard it differs in its obvious lack of sexual dimorphism. When Huber (1920) described the New Mexican Duck, no comparisons with other mallards were made, other than to say that it is apparently "a member of the Black Duck group." 


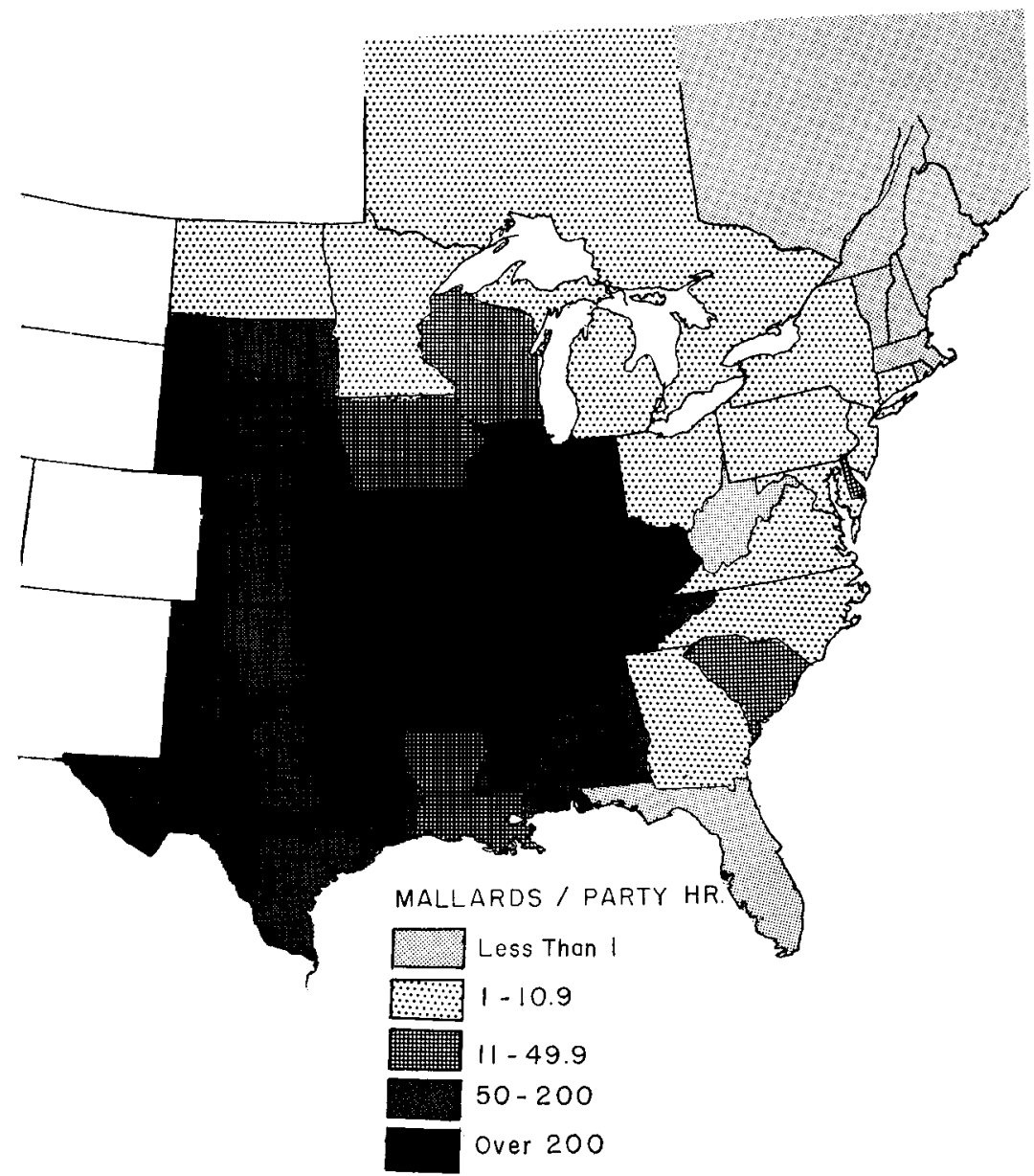

Figure 6. Relative densities of wintering Common Mallards, eastern states.

The Florida and Mottled ducks. The Florida Duck was stated (Rilgway, 1874) to differ from the Black Duck in the former's paler coloration, unmarked cheeks and throat, predominately ochraceous plumage tone, and (in males) a black spot at the base of the maxilla. The later description of the Mottled Duck, with its streaked cheeks, darker coloration, and less-distinct black mark on the maxilla, weakened these distinctions and left no clear-cut difference between these forms and the Black Duck.

The Black Duck. According to Kortright (1942), the Black Duck differs from the Mottled Duck by the former's olive-colored bill and the 
absence of a black spot at its base, by possessing a distinctly streaked throat, and by having narrower buffy edges to the feathers of the back.

\section{Methods and Materials}

It was evident from the confusion indicated above that a comparative study of plumage and soft-part differences among these forms must primarily include measures of variation of the relative darkness of body plumage, the degree of white barring on the secondary coverts, and bill coloration. Various supposed differences in speculum coloration (shown by Phillips, 1912, to be highly variable) and the degree of streaking on the throat, which appears to be related to the relative darkness of the body plumage, were not considered of major importance for study.

It was decided at the outset that any plumage comparisons would have to be made with reference to a standard that would extend over a range including both extremes as well as graded intermediate conditions. The "Hybrid index" system, which has been so successfully used by Andercon (1949), Sibley (1950), and others for estimating objectively phenotypical variations, seemed of possible application here. It was discovered that the plumages of female hybrid combinations between Mallards and Black Ducks corresponded so closely to those of pure Mexican, Florida, and Mottled ducks that patterns of corresponding feather regions could be considered identical. Therefore, it was decided to use pure female Mallards and Black Ducks for plumage extreme standards, and graded hybrid combinations for the intermediate conditions.

Applying the technique of the Hybrid index, the extreme represented by the lightest plumage condition was given a numerical value of " 0 ," and the darkest extreme was given a value of "4." The intermediate condition thus had a value of " 2 ," and the $1 / 4$ and $3 / 4$ conditions had values of " 1 " and " 3 ." In theory, an index number of " 2 " would result from an $F_{1}$ hybrid, and scores of " 1 " and " 3 " would be obtained from the two backcross combinations if no dominance were involved. Of course, wild-taken hybrids cannot be definitely established as such combinations, and in most cases probably would be the result of more complicated recombinations and segregations. However, by direct comparison with specimens in the Museum of Comparative Zoology at Harvard of known-parentage hybrids between Mallards and Black Ducks obtained from experimental breedings by Phillips (1915, 1921), it was possible to determine that no dominance was involved. Feathers from wild-taken hybrids from the Ithaca region, which closely corresponded to these known-parentage birds, were used as reference types. 
Six feather areas, which included the major points of plumage differences mentioned above, were selected for study. These areas were as follows:

Outer (6th) Rectrices (Row “A," Irigs. 7-9): Predominantly white in platyrhynchos, solid dusky in rubripes.

Scapulars (Row "B," Figs. 7-9): Wide terminal edge and three subterminal buff bars in flatyrhyuchos, narrow terminal edge and no barring in rubripes.

I lanks (Row "C," Figs. 7-9): Wide terminal edge and subterminal "V" in platyrhynchos, narrow terminal edge in rubripes.

Secondary Coverts (Row "D), Figs. 7-9) : Broad white subterminal bar in platyrhynchos, this absent or very faint in rubripes.

Under-tail Coverts (Row "E," Figs. 7-9) : Predominantly white in platyrhynchos, dusky with narrow buff edge in rubripes.

Breast (Row "F," Figs. 7-9) : Predominantly white with brown spots or crescent in platyrhynchos, dusky, usually with faint "V" and narrow buff edge in rubripes.

Representative feathers from these areas are shown in Figure 7, with pure female Mallard (" 0 ") ) at extreme left and pure female Black Duck ("4") at extreme right. This figure was used when determining index values of all females examined. Since the specimens from the populations cther than platyrhynchos and rubripes were obviously not hybrids, perhaps "Plumage index" rather than "Hybrid index" would be a more appropriate designation for the method as it was used here.

A valid comparison of males from all forms was impossible, owing to the sexual dimorphism present in the Mallard. For visual comparison only, the corresponding feathers from males of the Mallard, the Black Duck, and hybrid combinations that probably closely approach the typical $\mathrm{F}_{1}$ and the two backcross combinations are presented in Figure 8 . The blending type of inheritance, as well as a curious appearance of female characteristics in some of the hybrid feathers (e.g., flanks and rectrices), is of general interest.

To provide a means of objective evaluation of plumage differences in males, it was necessary to exclude the Mallard and devise a plumage index for the sexually nondimorphic forms only. This was accomplished by selecting feathers from males representing the lightest (diazi) and darkest (rubripes) extremes, and three graded conditions between them. The feather areas used were the same as in the females, and indeed the descriptions given for these feathers from the females apply equally well to the males. The index scoring was thus as follows:

$\begin{array}{cl}\text { Index No. } & \\ \text { "0" } & \text { Plightest, as in diazi, with wide buff and white areas } \\ \text { "1", } & \text { Mainly as in diazi, but reduced buff and white areas } \\ \text { "2", } & \text { Intermediate between diazi and rubripes } \\ \text { "3" } & \text { Mainly as in rubripes, but with slight barring present } \\ \text { Darkest, as in rubripes, with no barring present }\end{array}$


Published in the Auk (1961) 78. Copyright 1961, University of California. Used by permission. http://elibrary.unm.edu/sora

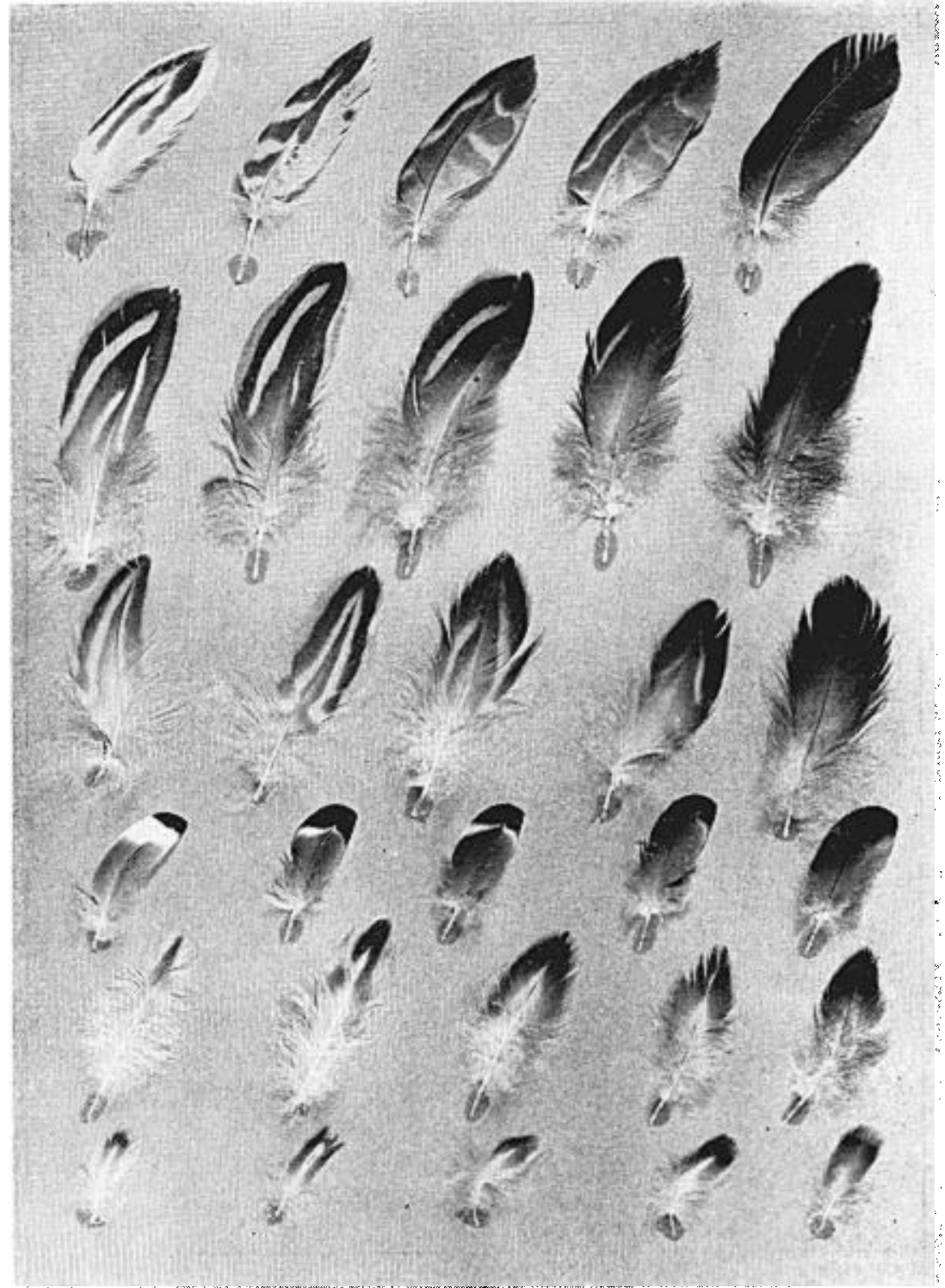

Figure 7. Reference chart of feathers from female Mallard (left), Black Duck (right), and hybrid combinations. Reading from top down, rows are $A$ to $F$ (in text). 
Published in the Auk (1961) 78. Copyright 1961, University of California. Used by permission. http://elibrary.unm.edu/sora

Auk

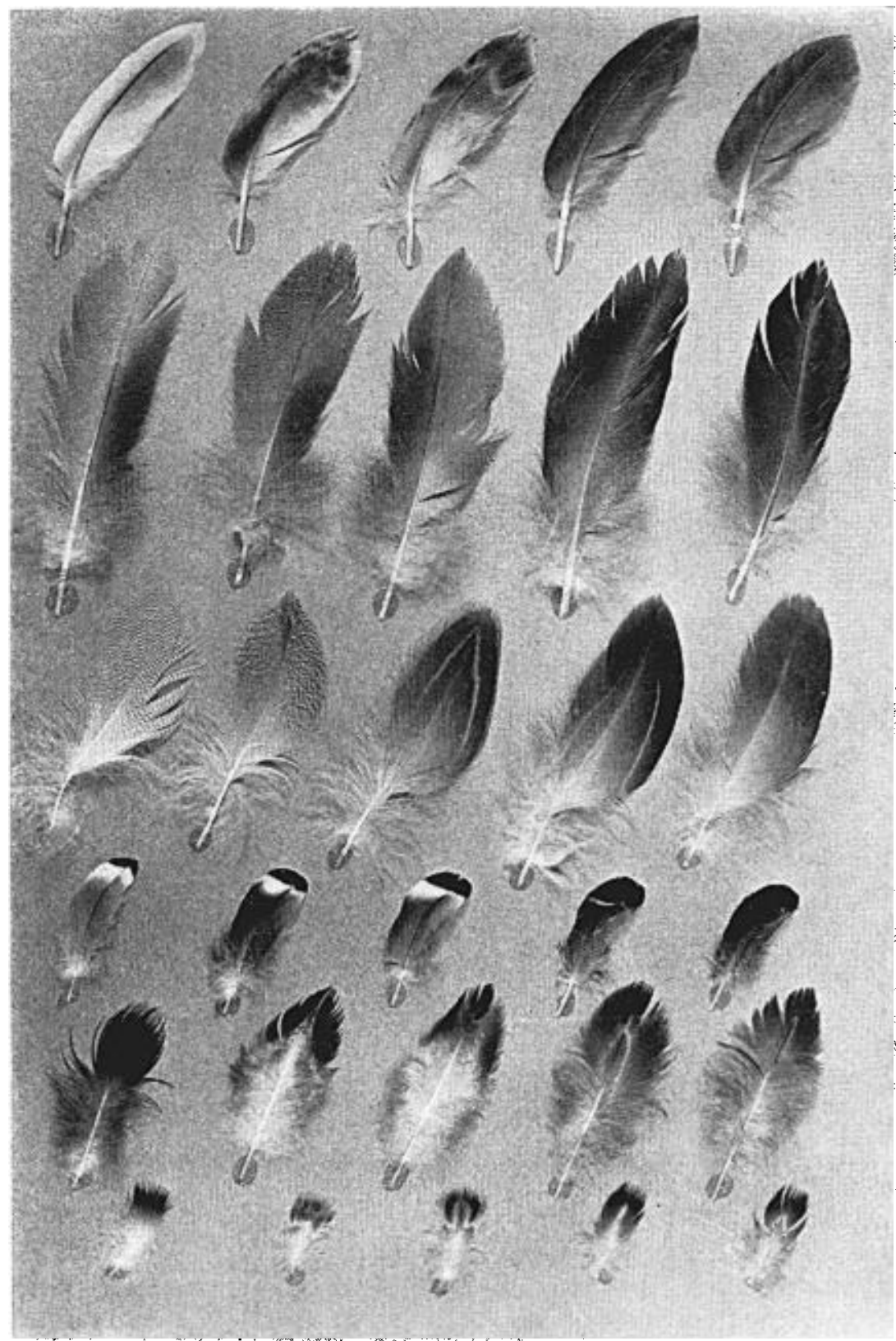

Figure 8. Chart of feathers from male Mallard (left), Black Duck (right), and hybrid combinations. Reading from top down, rows are $A$ to $F$ (in text). 
Published in the Auk (1961) 78. Copyright 1961, University of California. Used by permission. http://elibrary.unm.edu/sora

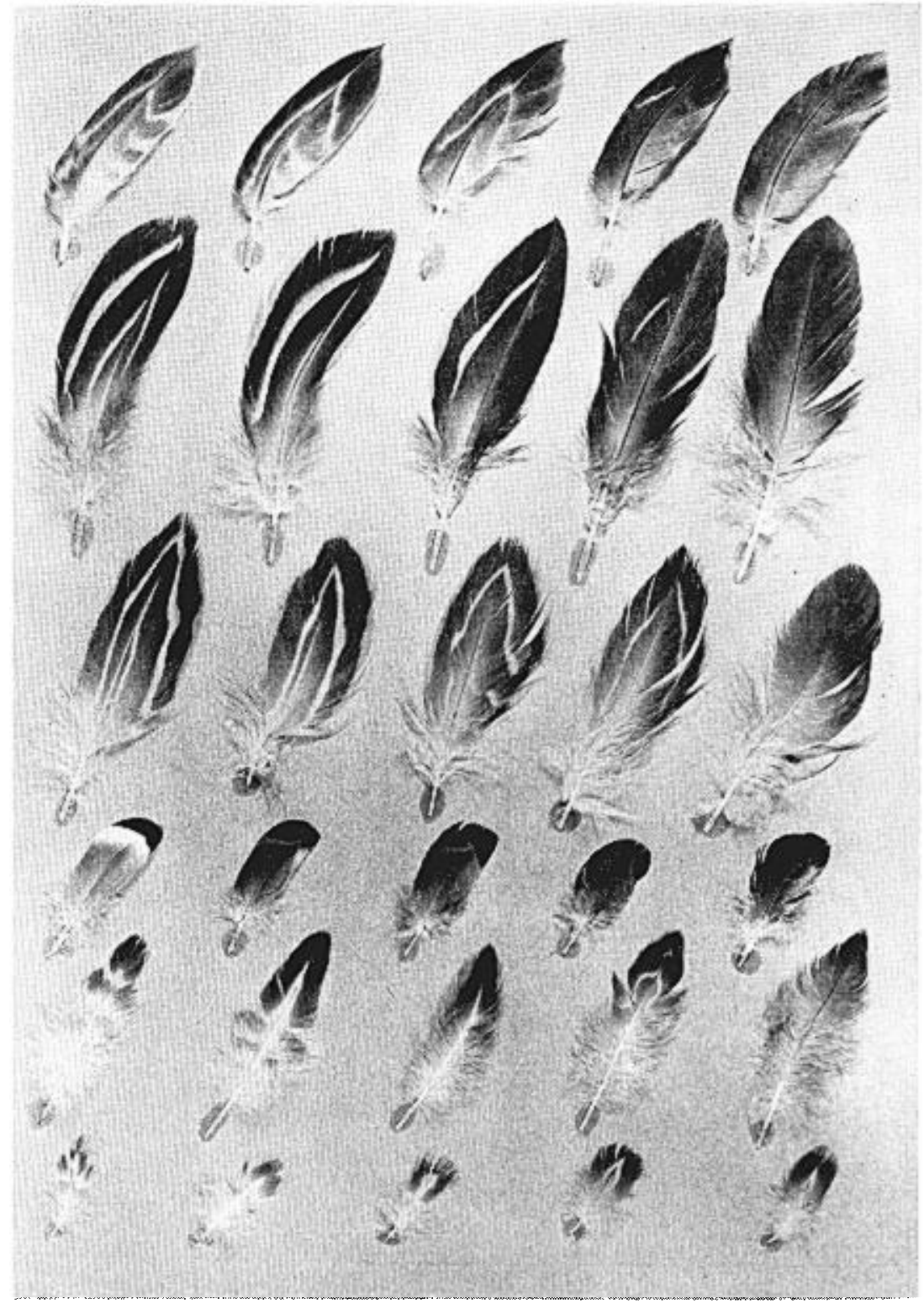

Figure 9. Reference chart of feathers from male Mexican Duck (left), Black Duck (right), and intermediate conditions. Reading from top down, rows are $A$ to $F$ (in text). 
These conditions are illustrated in Figure 9, the reference feather chart, with the left extreme representing " 0 " and the right extreme representing "4." In the case of both males and females, specimens that scored " 0 " for all six characters would receive a summed score of " 0 ," whereas those that scored " 4 " for all characters would receive a stmmed score of " 24. ."

Results

Index scores obtained for each feather region of all males and females examined are presented in Tables 2 and 3 . By totaling the number of observations for each index class in a given form, a combined estimate of that form's relative darkness may be obtained, which can be compared statistically with the estimate of any other form. These combined observations and a mean index value for each form are also tabulated in Tables 2 and 3. By constructing a contingency table and determining the chi square values for any two populations in question, the probable validity of separating those populations on a plumage basis may be determined. Using the index data for females, novimexicana was compared with diazi, and fulvigula was compared with maculosa. Too few male specimens of diazi and novimexicana were available for a similar comparison, but male specimens of fulvigula and maculosa were sufficient for testing. In the case of female novimexicana and diazi, no strong indication of distinctiveness $(p>0.05)$ between the two populations was found. However, in the case of both male and female specimens of fulvigula and maculosa, separation of the two was distinctly indicated $(p<0.01)$.

An alternative means of presenting index data, that of summing indices for each specimen and plotting the summed totals for each form, is presented in Figures 10-11. In this case data from novimexicana and diasi were combined, since they showed no indication of summed index differences that might be significant. These diagrams clearly illustrate the difficulties of finding clear-cut morphological distinctions between any populations except the extremes. A fairly evident difference between fulvigula and maculosa may be seen in this diagram, and it is of interest that those specimens (four) of maculosa that achieved the highest summed indices were from Texas, primarily the Brownsville area, rather than from Louisiana. It would be of interest to learn if the Mexican population of maculosa also exhibits this very dark coloration, but at present almost no specimens have been collected from that region.

Examination of soft-part coloration is very difficult from preserved specimens, and as a result no critical studies were made of these features. However, since some aspects of bill spotting have been stressed by the authorities on these forms, an attempt was made to obtain some informa- 


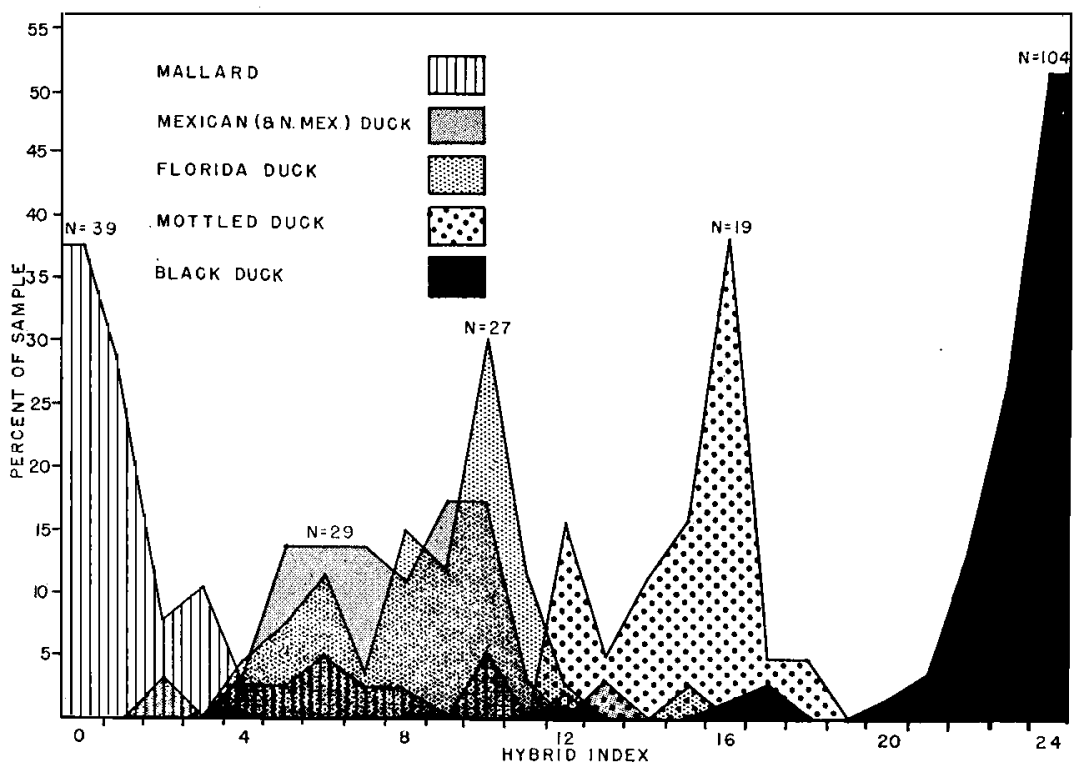

Figure 10. Distribution frequencies of summed indices, female specimens.

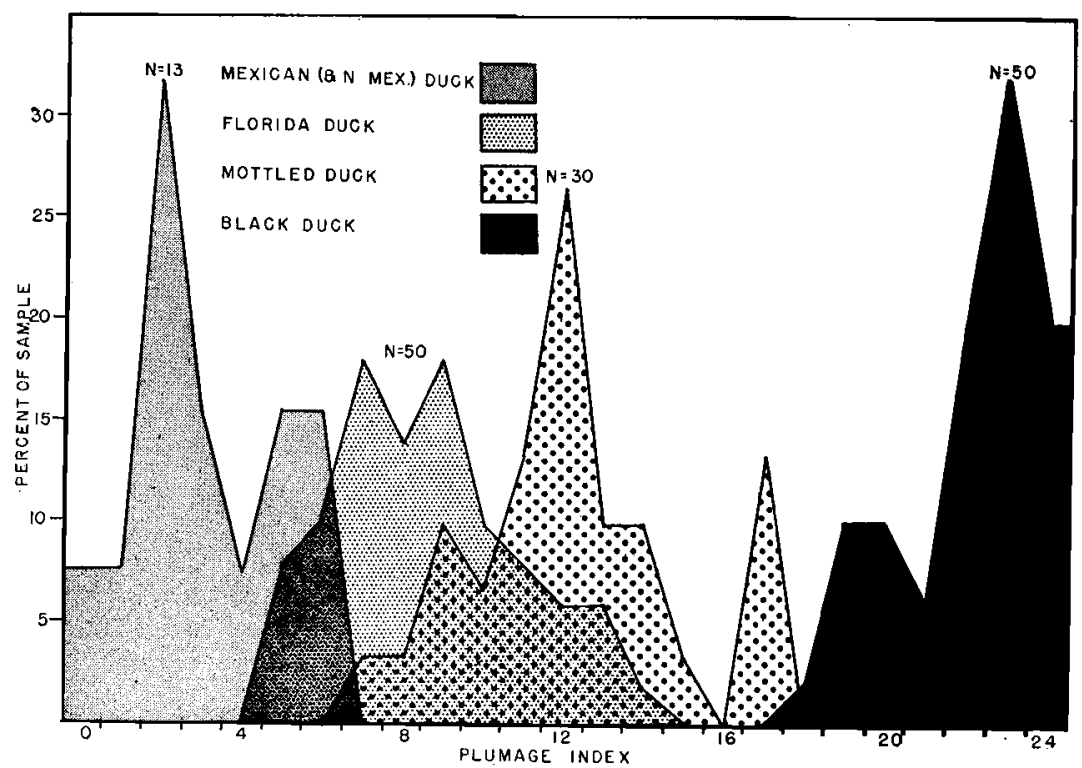

Figure 11. Distribution frequences of summed indices, male specimens. 
Published in the Auk (1961) 78. Copyright 1961, University of California. Used by permission. http://elibrary.unm.edu/sora

Auk

JoHNSGARD, Relationships among Mallards

TABLE 2

Summary of Index Data for Females

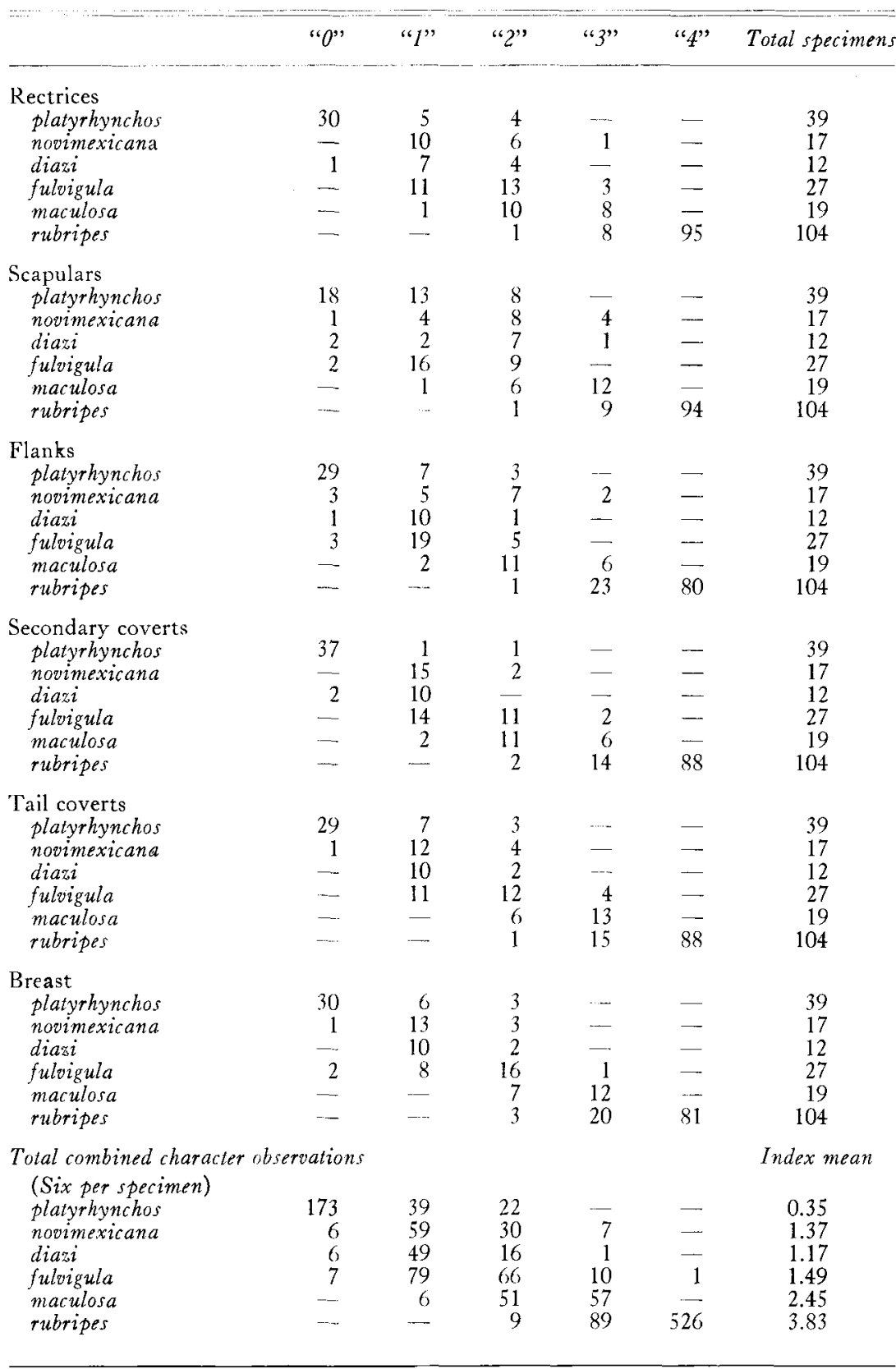


Published in the Auk (1961) 78. Copyright 1961, University of California. Used by permission. http://elibrary.unm.edu/sora

TABLE 3

Summary of Index Data for Males

\begin{tabular}{|c|c|c|c|c|c|c|}
\hline & $" 0 "$ & $" I "$ & "2" & "3" & "4" & Total specimens \\
\hline \multicolumn{7}{|l|}{$\begin{array}{l}\text { Rectrices } \\
\text { novimexicana } \\
\text { diazi } \\
\text { fulvigula } \\
\text { maculosa } \\
\text { rubripes }\end{array}$} \\
\hline $\begin{array}{l}\text { Scapulars } \\
\text { novimexicana } \\
\text { diazi } \\
\text { fulvigula } \\
\text { maculosa } \\
\text { rubripes }\end{array}$ & $\begin{array}{l}2 \\
2 \\
4 \\
2 \\
-\end{array}$ & $\begin{array}{r}7 \\
26 \\
5 \\
-\end{array}$ & $\begin{array}{l}\frac{2}{18} \\
16 \\
-\end{array}$ & $\begin{array}{l}- \\
- \\
2 \\
7 \\
1\end{array}$ & $\begin{array}{l}- \\
\overline{-} \\
\overline{49}\end{array}$ & $\begin{array}{r}4 \\
9 \\
50 \\
30 \\
50\end{array}$ \\
\hline $\begin{array}{l}\text { Flanks } \\
\text { novimexicana } \\
\text { diazi } \\
\text { fulvigula } \\
\text { maculosa } \\
\text { rubripes }\end{array}$ & $\begin{array}{r}3 \\
7 \\
15 \\
- \\
-\end{array}$ & $\begin{array}{r}- \\
2 \\
31 \\
15 \\
-\end{array}$ & $\begin{array}{r}1 \\
4 \\
9 \\
-\end{array}$ & $\begin{array}{r}- \\
\overline{6} \\
15\end{array}$ & $\begin{array}{l}\overline{-} \\
\overline{-} \\
\overline{35}\end{array}$ & $\begin{array}{r}4 \\
9 \\
50 \\
30 \\
50\end{array}$ \\
\hline $\begin{array}{l}\text { Secondary cove } \\
\text { novimexicana } \\
\text { diazi } \\
\text { fulvigula } \\
\text { maculosa } \\
\text { rubripes }\end{array}$ & $\begin{array}{l}3 \\
6 \\
- \\
- \\
-\end{array}$ & $\begin{array}{r}1 \\
3 \\
26 \\
5 \\
1\end{array}$ & $\begin{array}{l}\overline{-} \\
23 \\
18 \\
10\end{array}$ & $\begin{array}{r}- \\
1 \\
7 \\
17\end{array}$ & $\begin{array}{l}- \\
\bar{z} \\
\overline{22}\end{array}$ & $\begin{array}{r}4 \\
9 \\
50 \\
30 \\
50\end{array}$ \\
\hline $\begin{array}{l}\text { Tail coverts } \\
\text { novimexicana } \\
\text { diazi } \\
\text { fulvigula } \\
\text { maculosa } \\
\text { rubripes }\end{array}$ & $\begin{array}{l}3 \\
5 \\
- \\
- \\
-\end{array}$ & $\begin{array}{r}1 \\
4 \\
32 \\
13 \\
-\end{array}$ & $\begin{array}{r}- \\
\overline{18} \\
17 \\
2\end{array}$ & $\begin{array}{l}\overline{-} \\
\overline{-} \\
\overline{11}\end{array}$ & $\begin{array}{l}- \\
- \\
\overline{37}\end{array}$ & $\begin{array}{r}4 \\
9 \\
50 \\
30 \\
50\end{array}$ \\
\hline $\begin{array}{l}\text { Breast } \\
\text { novimexicana } \\
\text { diazi } \\
\text { fulvigula } \\
\text { maculosa } \\
\text { rubripes }\end{array}$ & $\begin{array}{l}2 \\
1 \\
- \\
- \\
-\end{array}$ & $\begin{array}{r}2 \\
8 \\
17 \\
1 \\
-\end{array}$ & $\begin{array}{c}- \\
25 \\
20 \\
1\end{array}$ & $\begin{array}{r}\overline{-} \\
\overline{8} \\
9 \\
20\end{array}$ & $\begin{array}{l}- \\
\frac{-}{29}\end{array}$ & $\begin{array}{r}4 \\
9 \\
50 \\
30 \\
50\end{array}$ \\
\hline \multicolumn{6}{|c|}{$\begin{array}{l}\text { Total combined character observations } \\
\quad \text { (Six per specimen) }\end{array}$} & Index mean \\
\hline $\begin{array}{l}\text { novimexicana } \\
\text { diazi } \\
\text { fulvigula } \\
\text { maculosa } \\
\text { rubripes }\end{array}$ & $\begin{array}{r}16 \\
26 \\
19 \\
2 \\
-\end{array}$ & $\begin{array}{r}5 \\
28 \\
145 \\
40 \\
1\end{array}$ & $\begin{array}{r}3 \\
114 \\
91 \\
13\end{array}$ & $\begin{array}{l}- \\
18 \\
44 \\
65\end{array}$ & $\begin{array}{r}- \\
- \\
4 \\
3 \\
221\end{array}$ & $\begin{array}{l}0.46 \\
0.52 \\
1.48 \\
2.03 \\
3.69\end{array}$ \\
\hline
\end{tabular}

tion on these points. The major question concerns the presence or absence of a black spot on the base of the maxilla of males. Ridgway (in Ferrari-Perez, 1886) used this character to separate fulvigula (present) from rubripes (absent), and likewise Kortright (1942) indicates that it is absent in rubripes. However, Shortt's plate in Kortright's volume, as well as that in Shortt's (1943) paper of soft-part colors of 
the Black Duck, shows this spot clearly. I have noted it on all live male Black Ducks in breeding condition that I have examined, but the oliveslate color of the rhamphotheca of preserved Black Duck specimens obscures this mark. It was also found to be present on all 17 of the male specimens of fulvigula and all 12 maculosa examined for it. It was absent from five male specimens of diazi, and thus appears to be typical of fulvigula, maculosa, and rubripes.

In summary it may be said that none of the described plumage or soft-part characters, aside from the sexual dimorphism of platyrhynchos, were found to be of absolute diagnostic value in differentiating any population from all other populations. It was found that the distinctive plumage characteristics of the two extremes, platyrhynchos and rubripes, are bridged by the other populations and exhibit the characteristics of these populations in hybrid individuals.

\section{The Genetic and Hormonal Basis of Sexual Dimorphism}

At this point, where it is apparent that the sexual dimorphism of the Common Mallard provides the only real qualitative morphological basis for distinction from the other populations, it is of prime importance to investigate the genetic basis for such dimorphism in order to ascertain the taxonomic "value" of this character. That is, are the genetic changes required for converting a highly sexually dimorphic phenotype to an essentially nondimorphic one so great that these phenotypes must be regarded as constituting two species? In all probability no one will ever be able to determine by how many genes one distinct species differs from another, but if it can be determined that the loss of sexual dimorphism is dependent upon only a very few genes, then the taxonomic value of such dimorphism must be considered slight.

It has been discovered that male Mallards can be "feminized" by orchidectomy, followed by the implantation of bits of ovarian material in the abdominal cavity (Goodale, 1918). Furthermore, the annual assumption of the "eclipse" plumage of the Mallard provides additional evidence that the male Mallard carries the genetic potentiality of female plumage patterns. However, such femalelike plumages can be obtained only during periods of little or no testicular activity, and thus would not provide an explanation for the permanently nondimorphic plumages of the forms concerned here. A genetic basis for the loss of sexual dimorphism in these forms is necessary, possibly similar to that found in some breeds of Domestic Fowl (e.g., Sebrights). In such breeds both sexes are normally hen colored, and the factor producing hen coloration in males is determined by a single, dominant autosomal gene (Hutt, 1949), which, in the presence of either male or female hormone, acts 
on the feather follicle and prevents the expression of male plumage. Gonadectomized birds, however, assume a more malelike plumage in the absence of sex hormones. Three female Black Ducks were ovariectomized during the present study, and plucked feather areas grew back normal feathers. Therefore it seems unlikely that the same mechanism that applies to the Domestic Fowl can be postulated for these ducks. However, it is most fortunate that experimental studies on the genetic nature of sexual dimorphism in the Mallard, Mottled Duck, and Black Duck have been conducted (Phillips, 1915, 1921), and these studies are so crucial to the evaluation of the genetic importance of sexual dimorphistn in waterfowl that they will be summarized here in detail.

Phillips hybridized males of "Florida Duck" (actually Mottled Duck from Louisiana), Black Duck, Pintail (Anas acuta), and Australian Gray Duck (Anas poecilorhyncha superciliosa) with female "Call Ducks" (domestic Anas platyrhynchos) of typical wild-type plumage. All of the crosses were extended to the $F_{2}$ generation, as well as to many of the backcross combinations. The restits he obtained (1921) for the three, mallardlike forms were:

Mallard x Florida Duck: $38 \mathrm{~F}_{2}$ males obtained. Two nearly pure Mallard types, three nearly pure Florida types. Backcrosses to Mallard female bring out many pure Mallards.

Mallard x Black Duck: $23 \mathrm{~F}_{2}$ males obtained. Two most extreme Mallard variates lack solid green head, white neck-ring, and light-colored, vermiculated abdomen. Backcrosses to Mallard females show no pure Mallard types.

Mallard x Australian Duck: $15 \mathrm{~F}_{2}$ males obtained. Very slight segregation. Most extreme Mallard type scarcely differs from $F_{1}$ individuals. Backcross to Australian female was the only one made, so not directly comparable with the other backcrosses.

In the mating between the Mallard and the Pintail, "the smallest possible amount of segregation was found, both in the straight $F_{2}$ generation and in backcrosses with the Pintail male." Regarding the Mallard $x$ "Florida" Duck crosses, Phillips (1921) states that the hybrids exhibit

The most extreme example of segregation thus far discovered in species crosses between either ducks or pheasants. Parental types are almost recovered from among $38 \mathrm{~F}_{2}$ males. Backcrosses to Mallard parent produce a more uniform generation of nearly pure Mallard types. The Florida Duck must be supposed to represent, from the genetic point of view, substantially a Mallard, with the male secondary sex characters not expressed.

He states further:

It is apparent then that in this species cross we have a nearer approach to orthodox Mendelism than in any other thus far reported among birds. Out of 38 males two were nearly pure Mallard types, and three almost pure female types, these latter closely resembling the Florida Duck parent. 
Although Phillips did not pursue this point, it should be stated that, according to the principle of multiple factor inheritance, a mating of two genotypes differing in a character by two pairs of independent, nondominant genes would produce in an $\mathrm{F}_{2}$ generation of 38 phenotypes an expected recovery of roughly four pure parental types (Sinnott et al., 1950). Judging from Phillips' description, the $F_{2}$ generation of this cross closely approximated these expected results. It seems justified therefore to state that the difference in male plumages between the Common Mallard and the "Florida" (Mottled) Duck is probably explainable by a genetic difference of the magnitude of two gene pairs.

As indicated by Phillips, the Mallard $x$ Black Duck $F_{2}$ generation exhibited less tendency toward segregation than the Mallard $\mathrm{x}$ Florida Duck cross, but more so than did the crosses involving the Australian Gray Duck and Pintail with Mallards. Thus we may conclude that the number of genes determining the Black Duck's plumage differences from the Mallard is greater than is the case with the Florida Duck, and fewer than the genetic differences between the plumages of the Mallard and the Australian Duck or Pintail. Phillips believed, however, that the Black Duck possesses the genetic capacity for assuming the male Mallard plumage. He states (1915):

We are thus led to the belief that the wild Black Duck actually contains Mallard characters not present in the Australian Duck, and that these are slightly accentuated by association in the zygote with characters from the Mallard parent. In other words, there is present in the wild Black Duck, latent Mallard characters, which sometimes appear with age. These characters become immediately apparent when a quarter dose of Mallard is combined with a three-quarter dose of Black Duck.

It would seem apparent that the described plumage differences that have been the basis for the erection, at one time or another, of six species of North American mallards are scarcely valid characters on which to base species judgments. This is emphasized not only by the evidently slight genetic variations that can effect these differences, but also by the considerable individual variation and overlap of characters attributed to the various forms.

\section{EgG-White Proteins}

\section{Introduction and Methods}

In conjunction with Dr. C. (i. Sibley's research on the electrophoretic characteristics of avian protein systems, an attempt was made to compare the egg-white proteins of as many of the forms under investigation as possible. The theoretical importance of protein similarities in determining phyletic relationships is now widely recognized. Comparative 
studies utilizing electrophoresis are of relatively recent development; the history, methodology, and theoretical basis of these techniques have been summarized by Sibley (1960).

Comparative electrophoretic egg-white studies on waterfowl were begun by McCabe and Deutsch (1952), who analyzed 37 species of birds, including eight of waterfowl. Sibley (1960) has reported on several additional species of Anatidae, including some material from the Mallard and the Black Duck that has been used in the present study. Equipment and techniques utilized have been described in detail by Sibley and Johnsgard (1959a, 1959b).

\section{Variation with Anas}

To illustrate the amount of variation that is encountered among diverse species of Anas (sensu Delacour), samples from species representing the extreme morphological variation have been selected for presentation. These are the Common Pintail (Anas acuta), Shoveler (Anas clypeata), and Gadwall (Anas strepera). Electrophoretic profiles of the egg-white proteins from these species are presented in Figure 12. These curves, projected on a centimeter scale, indicate the variability encountered in the stated sample size. Each of the samples was from a different egg. The uppermost of the three lines indicates the maximum vertical distance encountered in the combined profiles, the lowermost the minimum vertical distance, and the central line represents a mean profile sample, plotted optically, for each species. In all cases vertical variability is of least significance, relative height of the peak is of greater significance, and the horizontal mobility from the point of application (indicated by arrows) to each peak is of the greatest significance. Using the mean sample profiles of each species and superimposing them on the same chart provides an easy means of optical comparison. Thus it may be observed that the Gadwall possesses a higher peak in the ovoconalbumin region than do the other two species. The presumed ovomucoid and ovalbumin fractions of the Pintail have somewhat greater mobilities than have the corresponding fractions of the other species.

\section{Variation within the North American Mallards}

Within the mallard group, samples were obtained from the Mallard. the Florida Duck, and the Black Duck. These profiles are also presented in Figure 12. The Florida Duck profile was obtained from eight samples of a single, slightly incubated egg, whereas the others represent single samples from each of several fresh eggs. Therefore less credence can be placed in the results from the Florida Duck, and it is only included for the sake of completeness. The composite mean profiles from these 

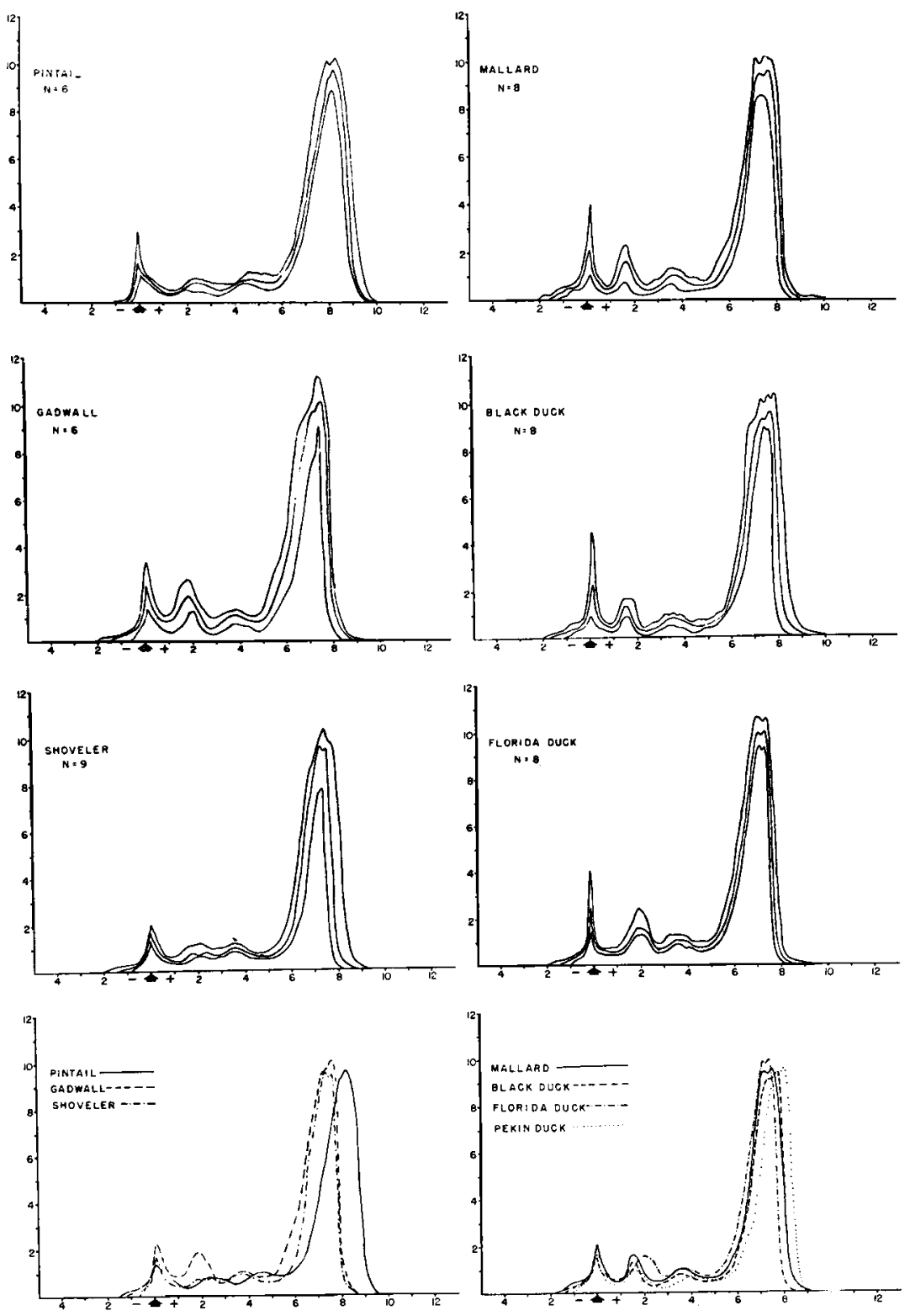

Figure 12. Electrophoretic profiles of egg-white protein samples (see text for explanation ). 
forms, plus domestic “Pekin” Mallard (Anas platyrhynchos), have been superimposed for easy comparison. It will be seen that the mean profiles of the Mallard and Black Duck are extremely similar, and in fact the Pekin profile exhibits greater difference from the wild form than does the Black Duck. Considering the inferior condition of the Florida Duck sample, it too shows a great similarity to the typical mallard profile, differing only in the mobility of the ovoconalbumin fraction. In the original profiles this fraction exhibited, by its indefinite and diffused borders, indications of having undergone partial chemical breakdown. It is very probable that fresh samples would show even closer similarity to the others.

\section{Sexual Behavior}

Data on the sexual behavior of Mallards and Black Ducks have been presented elsewhere (Johnsgard, 1960), and will be summarized briefly here, together with notes on the behavior of the other forms concerned.

The behavior of the Mallard has been extensively studied by Lorenz (1941; 1951-1953) and more recently by Weidmann (1956) and others. These studies have all indicated that there are three major male "courtship" displays that are primarily concerned with pair formation. These are, in Lorenz's terminology, the "Grunt-whistle," the "Down-up," and the "Head-up-tail-up" with associated "Nod-swimming." The female's courtship displays consist primarily of "Nod-swimming" and "Inciting." These same displays are found, with varying degrees of modification, in all the mallardlike ducks as well as in other closely related groups of surface-feeding ducks, but in these less closely related species qualitative as well as quantitative differences occur in the behavior of both sexes.

A study of the courtship displays among wild and semiwild Mallards and Black Ducks, during which over 3,000 Mallard and over 1,300 Black Duck displays were tallied, has failed to reveal any qualitative differences in the male courtship displays of these two forms. Female courtship displays were not included in the quantitative studies owing to their nondiscrete nature, but no qualitative differences were observed between Mallards and Black Ducks in these female displays. Only a few statistically significant quantitative differences were detected in the male courtship displays of Mallards and Black Ducks. Of these, the most striking difference was that male Black Ducks have a lower display threshold; i.e., in a given instance of male display more male Black Ducks are likely to display toward a female than would male Mallards in the same situation. It is suggested that this is a restlt of the Black Duck's absence of special male plumage characters, which likely intensify the need for a prompt and sensitive response to female signals. Secondly, male Black 
Duck displays tencled to be slightly more predictable and uniform than were male Mallard responses. This difference also was attributed to be the probable result of selection for specific male responses in the absence of male plumage differentiation.

A few observations on the behavior of Mallard x Black Duck hybrids were obtained for wild and captive individuals. Hybrids displayed with the same apparent intensity as did "pures" of each form, and also showed no deviation in qualitative features of display from the parental forms. All of the displays of the parental forms, including copulation, were observed in hybrids, but in too small numbers to submit to statistical analyses. Intermediate hybrids mingled with Mallard courting groups as frequently as with Black Ducks, although hybrids that were predominantly similar to one or the other parental form generally were found with the form they most resembled. Occasionally "pure" Mallards could be observed displaying in a group of Black Ducks or vice versa, but normally the courting groups of the two forms remained almost completely segregated.

No observations on the sexual behavior of the Mexican Duck were obtained, but captive specimens of the Florida Duck and Mottled Duck have been observed displaying. These observations are also too few to analyze statistically, but all the courtship displays of Mallards and Black Ducks have been observed in these races and in exactly the same situations and form as in Mallards and Black Ducks. Except for the slight plumage differences of all of the forms studied, it would be impossible to recognize whether a particular bird was a Mallard, a Florida Duck, a Mottled Duck, or a Black Duck on the basis of its sexual behavior.

\section{IsOLATING Mechanisms}

As shown earlier (Johnsgard, 1960), no qualitative differences in the behavior of male Mallards and Black Ducks were found that might serve as a basis for species recognition differences; indeed, no major quantitative differences were observed that might indicate a possible strengthening or diminution of any particular displays under the impact of selection against hybridization between the two forms. This means that, in a mixed population of unmated Mallards and Black Ducks, selective mating may otherwise be effected by (1) plumage differences in the males, (2) slight ecological or geographic distributional differences that would result in reduced probability of mixed pairing, or (3) differences in the temporal sequence of pair formation. The last-mentioned possibility may be ruled out on the basis of the behavioral studies cited above. The other points will be considered here. 
Correct mate selection by females on the basis of male plumage differences is an obvious and simple means by which the two populations could be maintained as perfectly discrete and separate entities; male Black Ducks can be distinguished from male Mallards at great distances by even the unpracticed human eye. That such a discrimination might exist cannot be argued; that it actually does occur and so results in "correct" mate choices is worth investigation. If sexual selection in mallards is actually as important as is suggested by the elaborate male plumage pattern of the Common Mallard, it must be concluded that female Mallards tend to select for mate the more brightly colored birds. There is some evidence to support this theory (Johnsgard, 1960). One wonders then if female Black Ducks, confronted with both dull-colored drake Black Ducks and the comparatively "gaudy" male Mallards, might not tend to "choose" the brighter bird. Lorenz (1941) found that in the sexually nondimorphic Meller's Duck (Anas melleri) females showed as strong a tendency to mate with male Mallards as with their own species. This could possibly also be true of the Black Duck, which is so similar in outward appearance to the Meller's Duck. Goodwin (1956), in a stimulating discussion of this problem, has pointed out the rather obvious effects of mixed mating. He states: "If the ducks of either species are less selective with regard to cross-matings, then that species will tend to be less successful if a surplus of drakes exists." That there exists a preponderance of drakes in adult flocks of both Mallards and Black Ducks cannot be questioned. Most available data indicate that between 50 and 60 per cent of the combined sex populations of Mallards and Black Ducks are males. This means that not all males can be successful in obtaining mates, and the effectiveness of sexual selection is thus enhanced.

In comparing resident populations of Mallards and Black Ducks in the Toronto area, Goodwin (1956) noted that since the introduction of a small stock of Mallards and Black Ducks in 1931 the two forms have hybridized "fairly freely and yet Mallards have increased rapidly in proportion to Black Ducks." He suggests that a selection against Black Ducks such as postulated above might be operating through a tendency towards nonselective mating or towards cross-mating in the case of the Plack Duck females. It would be most valuable to learn if most mixed pairing in the wild state involves male Mallards and female Black Ducks as would be expected, or, on the other hand, if female Mallards often mate with male Black Ducks. I have recorded or found reference to three pairings of the former type and six pairings of the latter kind, indicating that both combinations do occur, but the sample is far too small to suggest the favoring of either combination. 
In spite of the essentially identical nature of the displays of Mallards and Black Ducks, there is a surprising amount of separation in courting groups between the two forms when they occur on the same water area. Whether this is the result of mutual attraction among like-plumaged birds or a result of very slight differences in habitat preference is difficult to decide. The marsh-dwelling tendencies of the Mallard, as opposed to the forest- and maritime-inhabiting proclivities of the Black Duck, are certainly the most conspicuous differences to be found between the two forms. This was well documented by Benson (1937) who investigated the breeding ecology of the Black Duck on some natural water areas near Ithaca, New York. One of these areas, Spencer Marsh, closely approaches the typical cattail and tule-bordered marshes found in the western prairie states, whereas the others, Danby Pond and the Michigan Hollow swamp and Beaver Pond, are typical representatives of the woodland ponds of the eastern states. The more alkaline cattail marsh was actually found to contain many more waterfowl-food plant species than the wooded ponds. However, in the wooded swamp and ponds Black Ducks usually nest every year, whereas in Spencer Marsh they had not been recorded as nesting. Benson concluded that the Black Duck "is apparently cognizant of the fact that it needs a background of shadows afforded by swamps, woods, and numerous logs and stumps," and "is not nearly so much at ease on Spencer Marsh as on the Beaver Pond and Danby Pond." In his book on the Black Duck, Wright (1954) has also pointed out that during the breeding season the bird is essentially a "forest duck." This contention is further supported by a breeding study done on Kent Island, Maryland, where 80 per cent of 161 Black Duck nests were found in wooded areas (Stotts, 1955). Although the Mallard will, under unusual circumstances, nest sometimes in heavily wooded areas (Bent, 1923), this is a comparatively rare situation.

\section{Estrmation of Gene Pools and Hybridization Incidence}

From the data presented earlier, it is possible to estimate with a fair degree of certainty the approximate sizes of the gene pools of the populations involved. By assigning the Mallard populations of the eastern United States (Atlantic and Mississippi flyways) an arbitrary value of 100 , the relative estimated total population sizes of the other forms are as follows: Black Duck 17, Mottled Duck 0.91, Mexican Duck (including New Mexican population) 0.52, and Florida Duck 0.26. This clearly illustrates the comparatively small sizes of these southern populations and the ease by which they might theoretically be swamped. To determine how much, if any, interbreeding occurs among the sexually non- 
dimorphic forms where they are in contact would be impossible. However, in the two areas where the Mallard overlaps in its breeding range with these nondimorphic forms the presence of hybridization is easily proved.

A relatively small amount of breeding contact exists between the Mallard and the Mexican ("New Mexican") Duck in central and southern New Mexico. In regard to the frequency of hybridization, Lindsey (1946) states :

The extreme southern part of the Mallard's breeding range covers most of the known nesting range of the New Mexican Duck; frequent hybridization produces individuals showing widely varying proportions of the traits of the parental species. Almost any day in winter and early spring, interesting wild hybrids may be seen at close range, mingling with wild Mallards which also winter in the duck ponds at Rio Grande Park, Albuquerque. Hybrids usually outnumber the pure New Mexicans here; few of the latter winter this far north.

Except for this statement, no other estimate of hybridization incidence for the area is available.

It is somewhat easier to estimate the incidence of hybridization occurring between the Mallard and the Black Duck in the eastern United States, for the area of contact is much broader and a considerable amount of banding and hunter-kill data are available. No one has thus far accumulated such data with the intention of determining the exact hybridization incidence in any area, and these figures generally result from the occasional occurrence of a bird that cannot be readily classified as either a Mallard or Black Duck. Undoubtedly the great majority of recombinant individuals that only show slight deviations from the typical Mallard or Black Duck plumage patterns are not recorded as hybrids; juveniles, females, and males in nonbreeding plumage are also likely to be overlooked. However, to provide a very minimum estimate of hybridization incidence, an attempt was made to accumulate such data from a number of states. These data have been obtained primarily by directly contacting persons engaged in banding operations, as practically none of this kind of information has been published, and their assistance in compiling these figures is gratefully acknowledged. The most satisfactory data obtained in this way, from the standpoint of sample size (a minimum of 4,000 total birds), are presented in Table 4.

Nearly all of the persons contacted indicated that their figures only represented "obvious," or "pronounced," hybrids. Thus D. Handley, who provided the data from Ohio, states: "If minor hybrid characteristics were considered then the Mallard-Black hybrids would make up about five to ten per cent of the total Mallard and Black Duck populations." This would mean that the hybrid figures in this case should be 
TABLE 4

Minimum Mallard x Black Duck Hybridization Incidence, Various States

\begin{tabular}{|c|c|c|c|c|c|c|c|}
\hline State & Period & $\begin{array}{l}\text { No. } \\
\text { Mal- } \\
\text { lards }\end{array}$ & $\begin{array}{l}\text { No. } \\
\text { Blacks }\end{array}$ & $\begin{array}{l}\text { No. } \\
\text { hy- } \\
\text { brids }\end{array}$ & $\begin{array}{c}\text { Per cent } \\
\text { hy- } \\
\text { brids }\end{array}$ & $\begin{array}{c}\text { Percent } \\
\text { Mal- } \\
\text { lards }\end{array}$ & $\begin{array}{l}\text { Percent } \\
\text { hybrids } \\
\text { Blacks }\end{array}$ \\
\hline Ohio & 1950-1953 & 2,834 & 1,118 & 69 & 1.7 & 70.5 & 6.2 \\
\hline Delaware & $1951-1958$ & 2,160 & 2,489 & 74 & 1.5 & 42.5 & 2.5 \\
\hline Michigan & $1935-1958$ & 3,563 & 6,95 & 92 & 0.9 & 33.9 & 1.3 \\
\hline Vermont & $1946-1957$ & 335 & 3,647 & 19 & 0.5 & 8.4 & 0.5 \\
\hline Pennsylvania & 1948-1958 & 1,957 & 8,531 & 25 & 0.2 & 18.6 & 0.3 \\
\hline Maine & $1948-1957$ & 423 & 23,907 & 39 & 0.2 & 1.9 & 0.2 \\
\hline
\end{tabular}

multiplied by a correction factor of from between three to six, and the same can probably be safely stated for the other figures. Except for the data from Pennsylvania, there is a direct correlation between the percentage of recorded hybrids and the percentage of Mallards in the combined population. This might be interpreted to mean that a female Black Duck is more likely to mate with a Mallard where Mallards predominate than a female Mallard is likely to mate with a Black Duck where the latter predominate. It might, however, also simply mean that hybrids are more frequent where the two forms have been in contact longest, that is, in the western part of the Black Duck's range. In any event, it can be safely concluded that increased sympatry of range is likely to result in increased hybridization.

Unfortunately, no detailed data from the westernmost edge of the Black Duck's range could be located. Dr. W. H. Elder informed me (pers. comm.) that during his banding operations in Illinois Mallards comprised about 90 per cent of the combined Mallard and Black Duck catch, and that the ratio of Black Ducks to hybrids was approximately ten to one (about 700 to 70 ). Dividing this figure by two, there still remains at least 5 per cent of the Black Duck gene pool "tied up" in hybrids in that area.

No direct evidence that hybrids possibly are being selected against, either through reduced fertility or reduced ability to obtain mates because of intermediate characteristics, was obtained during this study or has been indicated by other studies. The complete spectrum of plumage variations from pure Mallard to pure Black Duck indicates that a sufficient number of hybrid matings occur to allow the phenotypic expression of every possible genetic recombination. For example the following numbers of wild male hybrids were observed at Howland's Island, New York, during a two-month period. Six almost pure Mallards, six predominantly Mallard, seven intermediate, eleven predominantly Black Duck, and eight almost pure Black Duck. If, however, hybrids actually are 
being selected against, the roughly six-to-one ratio of Mallards to Black Ducks in the eastern states can be interpreted to mean that for every mixed pair formed there results six times as much damage to the Black Duck gene pool as to that of the Mallard. If the hybrids are not selected against, and they mate randomly with both Mallards and Black Ducks, then the possibility of eventual swamping of the Black Duck gene pool is six times greater than the alternative possibility.

In summary, these following points place the Black Duck at a selective disadvantage: (1) Its smaller gene pool will be affected much sooner by disadvantageous hybridization or possible swamping than will that of the Mallard, (2) the male Black Duck's sexually nondimorphic plumage and lack of special signal characters are, theoretically at least, of less sexual selection value than are those of the Mallard in a mating situation where sexual selection is intense, and ( 3 ) forest clearing, farm pond construction, and more intensive land use in the eastern states have resulted in continually decreasing Black Duck, and increasing Mallard, habitat.

\section{Evolutionary Implications and Taxonomic Conclusions}

The extremely wide Holarctic range of the Common Mallard leaves little doubt that it is the oldest of the forms under discussion, and can probably be regarded as being closest to the ancestral form. I also believe that the sexually dimorphic condition of the Common Mallard is of long standing, for a strikingly similar plumage pattern is found in the otherwise well-differentiated and allopatric Australian and New Zealand Chestnut-breasted and Brown Teals (Anas castanea-Anas auklandica complex), which must have been isolated from the Mallard for a much longer period than any of the populations under consideration here. Of these latter forms, I believe that the degree of genetic difference from the Common Mallard, from least to greatest, is indicated by the sequence diazi< maculos $\cong$ fulvigula $<$ rubripes.

Isolation of the Black Duck from the ancestral mallard stock probably originated through the establishment of an eastern population that was separated by the hardwood forests from the prairie populations of Anas. Such isolation would allow for the loss of sexual dimorphism through reduced pressures for species recognition (Sibley, 1957). Probably this coastal population gradually moved westward and northward into the swamps and waterways of the hardwood and evergreen forests, where selection for a darker, concealing, body plumage would likely obtain. By the time the population had extended far enough westward to establish a secondary contact with the prairie mallards, sufficient habitat adaptation had presumably been evolved to reduce greatly the actual contact between the two forms. 
Much more recently, breeding populations of mallards were established on the central plateau and eastern coasts of Mexico. This may have occurred during a period of glaciation, when the prairie mallard population was forced southward and the ancestral Black Duck population was restricted to the southeastern states. Lakes in the central plateau of Mexico were apparently much more extensive during this period (Jaeger, 1925 ), and suitable breeding habitat nay have likewise been much more extensive. I ater, when the warmer and drier postglacial clinate resulted in a drying up of many of these pluvial lakes and caused a northward movement of waterfowl populations, a small, residual population of mallards probably remained on the few areas of suitable habitat on the plateat. At the same time, the coastal population, separated from the plateau population by an altitudinal barrier of 7,000 feet, probably began to extend northward along the Gulf Coast. Both the coastal and plateau populations probably lost their sexual dimorphism rapidly, judging from the simple genetic control of this character, in response to a lack of other sympatric breeding species of Anas. The coastal population also evolved a darker plumage, presumably in response to its more humid environment. This was achieved by the same mechanical, if not genetic, mechanism as in the Black Duck, that is, by the reduction in width of the buff edging and bars of the contour feathers. The plateau population, however, remained essentially unchanged in this respect. Eventually part of the coastal population reached peninsular Florida (after crossing an area of apparently now relatively unfavorable habitat along the coasts of Mississippi, Alabama, and western Florida) and established a semi-isolated population in the southern part of that state.

This explanation thus hypothesizes the establishment of three major isolated populations from parental prairie mallard stock, each of which independently evolved sexually nondimorphic plumage and varying degrees of darker coloration. The same mutations may, however, have been utilized in some cases to achieve these ends. As indicated earlier, the Black Duck may have lost its sexual dimorphism by an inhibition of the genetic basis for this character, whereas in the Mottled Duck at least the genes governing it seem to have been eliminated.

I am in firm agreement with Delacour (1956) that diazi and fulvigula should be considered subspecies of Anas platyrhynchos, and likewise agree that novimexicana is inadmissible and should be synonymized with diazi. Results of the plumage study, however, force me to conclude that maculosa is a valid race, a determination in opposition to Delacour's opinion. 
An accurate and completely satisfactory disposition of rubripes cannot, in my opinion, be made. No modern taxonomist has as yet formally proposed the conspecificity of rubripes and platyrhynchos, although the possibility has been suggested (Baillie, in Goodwin, 1956). Delacour (1956) states that only the rather wide area of sympatry in breeding ranges prevents this interpretation. Dr. Milton Trautman, who has studied the Black Duck carefully for many years, has concluded (in litt.) that "the Black and Mallard probably are not 'good' species as we normally define species in birds, but that they are 'potential' species which as yet have developed no genetic isolation but which display marked (subspecific at least) habitat differences and a marked mutation in coloration." I completely agree with this opinion, and feel that these habitat differences are of greater significance than is the relatively recent sympatry of the forms. The marked separation of the two when they are inhabiting the same water area and the relatively infrequent occurrence of mixed courting groups indicate that recognition capacities are well developed. Hybrid frequency also indicates that pairing is far from random in wild populations.

Arguing against the species-distinctness of the forms are the apparently complete hybrid fertility, the great morphological (including both plumage and egg-white proteins) similarities, the essentially identical sexual behavior, and the evidence for increasing hybridization associated with increasing sympatry. In addition, there is no indication of any tendency toward the development of any unique signal characters. Thus, depending upon one's viewpoint, evidence can be marshaled either to treat the two forms as subspecies or as species. There is little probability that speciation in the Black Duck will progress any further because of the extensive secondary contact, and indeed it is possible that the form will eventually become so genetically intermixed with the Mallard that specific recognition will be impossible from a practical as well as a theoretical standpoint. I, therefore, believe that the most satisfactory status for rubripes is to consider it a subspecies of Anas platyrhynchos, but one that exhibits a greater degree of differences in ecological preference and social segregation than normally occurs in subspecies. Neither a subspecific nor a specific relegation can be entirely satisfactory at present, and only time and continued investigations are likely to prove or disprove the conclusions reached here.

\section{AcKNowledgments}

The original data formed the basis for a doctoral dissertation, which was submitted to the Graduate School of Cornell University on 15 June 
1959. I would like to express my sincere appreciation to my committee chairman, Dr. Charles G. Sibley, for his continued assistance and advice. For financial aid in the form of fellowships I am indebted to Cornell University and the National Science Foundation. The State University of New York provided a summer research honorarium in 1957. The use of aviary facilities for keeping ducks, and the opportunity to utilize the electrophoretic equipment there, is gratefully acknowledged. My other committee members, Drs. L. C. Cole, W. C. Dilger, and A. van Tienhoven, provided various kinds of assistance; Dr. Dilger's helpfulness in allowing my use of his motion picture equipment was especially appreciated.

For the use of unpublished data or other assistance I am most grateful to C. E. Addy, D. Benson, W. Bock, J. F. Cassel, E. B. Chamberlain, P. Claude, M. W. Coulter, W. F. Crisey, W. H. Elder, R. J. Fleetwood, W. L. French, J. Hagar, D. Handley, A. S. Hawkins, O. H. Hewitt, S. Hoyt, J. A. Imhof, R. Latimer, A. S. Leopold, A. A. Lindsey, J. Lynch, D. F. McKinney, A. Merriam, W. R. Miller, R. S. Palmer, M. D. Pirnie, F. A. Pitelka, M. M. Smith, R. I. Smith, R. H. Smith, M. B. Trautman, and D. A. West. Egg-white materials or birds were provided by the New York State Department of Conservation, the Delta Waterfowl Research Station, the Wildfowl Trust, J. Martin, J. Kiracofe, B. Dane, and R. E. Phillips. Use of museum facilities at Cornell University, the American Museum of Natural History, and the Museum of Comparative Zoology at Harvard College is acknowledged.

\section{SUmmary}

A comparative morphological, behavioral, and electrophoretic study was undertaken on six populations of North American mallards that are currently considered by the A.O.U. Check-list to comprise four species and two additional subspecies. These include Anas $p$. platyrhynchos, A. d. diazi, A. d. novimexicana, A. f. fulvigula, A. f. maculosa, and $A$. rubripes. These forms are essentially allopatric in their breeding distributions, with the major exception of $A$. p. platyrhynchos and $A$. rubripes, which overlap throughout a several-hundred-mile zone in east-central United States.

Geographic ranges and population sizes are estimated, and evidence is presented to indicate that the present sympatry of rubripes and platyrhynchos is of recent origin and is rapidly increasing. Plumage differences in the populations were investigated by the "Hybrid index" method, and it was concluded that, except for the sexual dimorphism of platyrhynchos, only minor quantitative differences in feather patterns differ- 
entiate the populations. Evidence from experimental hybridization was presented to show that the genetic basis for the sexual dimorphism of platyrhynchos is relatively simple, and should not be considered an important taxonomic criterion. Analysis of the sexual behavior of male platyrhynchos and rubripes failed to reveal any important differences other than slight differences in male response thresholds. Electrophoretic studies of the egg-white proteins of platyrhynchos, rubripes, and fulvigula likewise failed to show any noticeable differences in the proportions and electrophoretic characteristics of these proteins.

A discussion of ecological, geographic, and behavioral isolating mechanisms of the populations, and the incidence of hybridization where they overlap resulted in the conclusion that none of the forms could reasonably be considered specifically distinct from any or all of the others. It is recommended that diazi, fulvigula, and maculosa be considered geographic races of Anas platyrhynchos, and that novimexicana be considered a synonym of diazi. It is also concluded that rubripes cannot satisfactorily be considered a distinct species and that increasing hybridization indicates that it might eventually be necessary to consider it a subspecies of Anas platyrhynchos.

\section{Literature Cited}

Allen, J. A., et al. 1908. Fourteenth supplement to the A.O.U. check-list. Auk, 25: 345-399.

American Ornithologists' Union, 1957. Check-list of North American birds. Fifth ed. 691 pp.

Anderson, E. 1949. Introgressive hybridization. John Wiley \& Sons, N. Y.

Arellano, M. and P. Rojas. 1956. Aves acuaticas migratorias en Mexico. I. Instituto Mexicano de Recursos Naturales Renovables, A.C. Mexico, D.F. $270 \mathrm{pp}$.

Benson, D. 1937. Studies in the ecology of the Black Duck, Anas rubripes Brewster. M.S. thesis, Cornell U., Ithaca.

Bent, A. C. 1923. Life histories of North American wild fowl. Bull. 126, U.S. Nat. Mus. 244 pp.

Brewster, W. 1902. An undescribed form of the Black Duck (Anas obscura). Auk, 19: 183-188.

Brewster, W. 1906. The birds of the Cambridge region of Massachusetts. Mem. Nutt. Orn. Club, Cambridge. 426 pp.

Brewster, W. 1909. Something more about Black Ducks. Auk, 26: 175-179.

Brewster, W, 1910. Resurrection of the Red-legged Black Duck. Auk, 27: 323-333.

Conover, H. B. 1922. Anas diasi novimexicana and Grus americana in Nebraska. Auk, 39: 412 .

Coulter, M. W. 1953. Mallard nesting in Maine. Auk, 70: 490.

Coclter, M. W. 1954. Some observations of Mallards in central Maine. Bull. Me. Aud. Soc., 10: 20-23. 
Delacour, J. 1956. The waterfowl of the world. Vol. II. Country Life, London. $232 \mathrm{pp}$.

Delacour, J. and E. Mayr. 1945. The family Anatidae. Wilson Bull., 57: 3-55.

Dwight, J. 1909. The singular case of the Black Duck of North America. Auk, 26: $422-426$.

Ferrari-Perez, F. 1886. Catalogue of animals collected by the Geographical and Exploring Commission of the Republic of Mexico, with descriptions of five new species, and critical remarks on others of great or less rarity or interest by Robert Ridgway. Proc. U.S. Nat. Mus., 9: 125-199.

Goodale, H. D. 1918. Feminized male birds. Genetics, 3: 276-299.

Goobwin, C. E. 1956. Black Duck and Mallard populations in the Toronto area. Ont. Field Biologist, $10: 7-18$.

Heilmayr, C. E. and H. B. Conover. 1948. Catalogue of the birds of the Americas. Pt. 1, No. 2. Pub. Field Mus. Nat. Hist., Zool. Ser., Vol. 13. $434 \mathrm{pp}$.

Howeld, A H. 1932. Florida bird life. Florida Dept. of Game and Fresh Water Fish. 579 pp.

Huber, W. 1920. Description of a new North American duck. Auk, 37 : 273-274.

Hutt, F. B. 1949. Genetics of the fowl. McGraw Hill, N.Y. 590 pp.

Iмноғ, T. A. 1958. Recent additions to the avifauna of Alabama. Auk, 75: 354-357.

JAEGER, F. 1925. Untersuchungen über das diluviale Klima in Mexico. Zeitschr. Gesell. für Erdkunde, Berlin. No. 9-10: 366-373.

JoHNSGARD, P. A. 1960. A quantitative study of the sexual behavior of Mallards and Black Ducks. Wilson Bull., 72: 133-155.

Kortright, F. H. 1942. The ducks, geese and swans of North America. Wildl. Mgmt. Inst., Washington. 476 pp.

LeOPOLd, A. S. 1959. Wildlife of Mexico-The game birds and mammals. U. of Calif. Press, Berkeley. 568 pp.

Lindsey, A. A. 1946. The nesting of the New Mexican Duck. Auk, 63 : 483-492.

Lönnberg, E. 1906. Einige Nomenklaturfragen. Jour. für Orn., 54: 528-533.

LoRenz, K. Z. 1941. Vergleichende Bewegungsstudien an Anatinen. Jour. für Orn., 89: 194-294.

Lorenz, K. Z. 1951-1953. Comparative studies on the behaviour of the Anatinae. Avic. Mag., 57: 157-182; 58: 8-17, 61-72, 86-94, 172-184; 59: 24-34, 80-91.

Lowery, G. H., JR. 1955. Louisiana birds. La. State Univ. Press. 556 pp.

MCCABE, R. A. and H. F. Deutsch. 1952. The relationships of certain birds as indicated by their egg white proteins. Auk, 91: 1-18.

Manning, T. H. 1952. Birds of the West James Bay and southern Hudson Bay coasts. Nat. Mus. Can. Bull. 125. 113 pp.

Oberholser, H. C. 1938. The bird life of Louisiana. Louisiana Dept. Cons. Bull., $28: 1-834$.

Peters, J. L. 1931. Check-list of birds of the world. Vol. 1. Harvard Univ. Press. 354 pp.

Phillips, J. C. 1912. A reconsideration of the American Black Ducks with special reference to certain variations. Auk, 29: 295-306.

Phillips, J. C. 1915. Experimental studies of hybridization among ducks and pheasants. Jour. Exper. Zool., 18: 69-144.

Phillips, J. C. 1920. Habits of the two Black Ducks, Anas rubripes rubripes and Anas rubripes tristis. Auk, 37: 289-291. 
Phillips, J. C. 1921. A further report on species crosses in birds. Genetics, 6: 366-383.

Phillips, J. C. 1924. A natural history of the ducks. Vol. 11. Longmans, London. $409 \mathrm{pp}$.

Pirnie, M. D. 1928. The plumage changes of certain waterfowl. Ph.D. thesis, Cornell University, Ithaca.

Ridgway, R. 1874. Notes upon American water birds. Amer. Nat., 8: 108-111.

RidgWAy, R. 1878. Descriptions of several new species and geographical races of birds contained in the collection of the United States Museum. Proc. U.S. Nat. Mus., 1: 247-255.

RiDGWAy, R, 1886. Preliminary descriptions of some new species of birds from southern Mexico, in the collection of the Mexican Geographical and Exploring Commission. Auk, 3: 331-333.

SAunders, G. B. 1952. Waterfowl wintering grounds of Mexico. Trans. 17th North American Wildl. Conf., pp. 89-100.

Saunders, G. B. 1953. The Tule Goose (Anser albifrons gambelli), Blue Goose (Chen coerulescens) and Mottled Duck (Anas fulvigula maculosa) added to the list of the birds of Mexico. Auk, 70: 84-85.

SAUnders, G. B. and D. C. Saunders. 1948. Report on migratory waterfowl investigations in Mexico. U.S. Fish and Wildlife Service, 107 pp. mimeo.

Sennetr, G. B. 1889. A new species of duck from Texas. Auk, 6: 263-265.

Shortt, T. M. 1943. Correlation of bill and foot coloring with age and season in the Black Duck. Wilson Bull., 55: 1-7.

Sibley, C. G. 1950. Species formation in the Red-eyed Towhees of Mexico. Univ. Calif. Pub. Zool., 50: 109-194.

Sibley, C. G. 1957. The evolutionary and taxonomic significance of sexual dimorphism and hybridization in birds. Condor, 59: 166-191.

Sibley, C. G. 1960. The electrophoretic patterns of avian egg-white proteins as taxonomic characters. Ibis, 102: 215-284.

Sibley, C. G. and P. A. Johnsgard. 1959a. Variability in the electrophoretic patterns of avian serum proteins. Condor, $61: 85-95$.

Sibley, C. G. and P. A. Johnsgard. 1959b. An electrophoretic study of egg-white proteins in twenty-three breeds of the Domestic Fowl. Amer. Nat, 93: $107-115$.

Sincock, J. L. 1957. Quarterly progress report for investigations project. Florida Waterfowl Investigations. 18 pp. mimeo.

Singleton, J. R. 1953. Texas coastal waterfowl survey. F.A. Report Series No. 11. Texas Game and Fish Comm., Austin. 128 pp.

Sinnott, E. W., L. C. Dunn, and T. Dobzhansky. 1950. Principles of genetics. McGraw Hill, N.Y. 505 pp.

Sprunt, A., Jr. 1954. Florida bird life. Cowand-McCann Inc., N.Y., and the Nat. Audubon Soc. 527 pp.

Stewart, R. E. 1958. Distribution of the Black Duck. U.S. Fish and Wildlife Circular $51.8 \mathrm{pp}$.

Stotтs, V. 1955. Black Duck breeding study ends in the Kent Island areas. Md. Tidewaters News, 12 (4) : 1-4. 
Townsend, C. W, 1905. The birds of Essex County, Massachusetts. Mem. Nutt. Orn. Club, Cambridge. 352 pp.

Townsend, C. W. 1912. The validity of the red-legged subspecies of Black Duck. Auk, 29 : 176-179.

Weidmann, U. 1956. Verhaltensstudien an der Stockente (Anas platyrhynchos L.). Das Aktionssystem. Zeitschr. für Tierpsychologie, 13: 208-271.

Wright, B. S. 1954. High tide and an east wind. Stackpole Co., Harrisburg. 162 pp.

The Wildfozol Trust, Slimbridge, Glos., England. 